Revista Eletrônica de Direito Processual - REDP.

Rio de Janeiro. Ano 10. Volume 17. Número 2. Julho a Dezembro de 2016

Periódico Semestral da Pós-Graduação Stricto Sensu em Direito Processual da UERJ

Patrono: José Carlos Barbosa Moreira. ISSN 1982-7636. pp. 579-622

www.redp.uerj.br

\title{
EMBARGOS DE DECLARAÇÃO NO PROCESSO ELEITORAL: BREVE \\ RELEITURA APÓS A VIGÊNCIA DO CPC-2015 ${ }^{1}$
}

THE APPEAL CALLED “EMBARGOS DE DECLARAÇÃO” IN

ELECTORAL PROCESS: A BRIEF VIEW AFTER THE BRAZILIAN NEW CIVIL

PROCEDURE CODE

Rodrigo Mazzei

Mestre pela Pontifícia Universidade Católica de São Paulo (PUC/SP) .Doutor pela Faculdade Autônoma de Direito (FADISP). Pós doutorado (UFES - bolsa CAPES-REUNI). Professor do curso de mestrado da Universidade Federal do Espírito Santo (UFES). Vice-presidente do Instituto dos Advogados do Estado do Espírito Santo (IAEES). Presidente da Escola Superior da Advocacia no Espírito Santo (ESAOAB/ES). Ex-Juiz do Tribunal Regional Eleitoral do Espírito Santo (TRE-ES).

reismazzei@gmail.com

RESUMO: Este artigo analisa a regulamentação dos embargos de declaração no seio do processo eleitoral, bem como a interpretação que tem sido dada pelos Tribunais Superiores. Aborda questões essenciais dos embargos de declaração, como prazo, natureza jurídica, hipóteses de cabimento e efeito suspensivo, muitas das quais objeto de discussão na doutrina e jurisprudência devido, sobretudo, à diversificação e variedade das normas que tratam do assunto (Código Eleitoral, regimentos internos dos Tribunais e Código de Processo Civil e Código de Processo Penal - aplicados subsidiariamente), além da necessidade de uma interpretação voltada à natureza constitucional da espécie recursal. Observa as propostas do Projeto do Novo CPC, em trâmite legislativo, para a regulamentação dos embargos de declaração e os impactos que esse novo texto trará ao processo eleitoral, pontuando possíveis caminhos para a conciliação entre o "novo" processo civil e o ordenamento eleitoral.

\footnotetext{
${ }^{1}$ Artigo recebido em 27/05/2016 e aprovado em 25/07/2016.
} 
Revista Eletrônica de Direito Processual - REDP.

Rio de Janeiro. Ano 10. Volume 17. Número 2. Julho a Dezembro de 2016

Periódico Semestral da Pós-Graduação Stricto Sensu em Direito Processual da UERJ

Patrono: José Carlos Barbosa Moreira. ISSN 1982-7636. pp. 579-622

www.redp.uerj.br

PALAVRAS-CHAVE: embargos de declaração; processo eleitoral; tribunais superiores; interpretação; natureza constitucional; novo CPC.

ABSTRACT: This paper analyzes the regulation of embargos de declaração with in the electoral process, as well as the interpretation that has been given by the Courts. Addressing essencial issues of embargos de declaração, as the deadline, legal nature, suitability hypothesis and suspensive effect, many of which are the subject of discussion in doctrine and jurisprudence, mainly due to diversification and variety of rules dealing with the subject (Electoral Code, Regiments Internal of Courts and Civil Procedure Code and Criminal Procedure Code - alternatively applied), besides the need for a constitutional interpretation focused on the embargos de declaração. Observes the proposals of the Project of the New CPC, pending in the legislative, for the regulation of embargos de declaração and the impacts that this new text will bring to the electoral process, pointing out possible ways to conciliation between the "new" civil process and the electoral law.

KEYWORDS: embargos de declaração; electoral process; courts; interpretation; constitutional nature; new Civil Procedure Code.

SUMÁRIO: 1. Do Objeto do Trabalho 2. O Código Eleitoral como Superfície Legal dos Embargos de Declaração no Processo Eleitoral 3. Prazo para Manejo dos Embargos de Declaração 4. Natureza Jurídica 5. Hipóteses de Cabimento 6. Das Decisões Embargáveis 7. Embargos de Declaração e o Princípio da Fungibilidade 8. Da Preservação do Prazo para outros Recursos 9. Efeito Suspensivo (Propriamente Dito) 10. Os Embargos de Declaração no "Novo" Código de Processo Civil 10.1 As Principais Questões que Envolvem Prazo para Manejo 10.2 Cabimento contra qualquer tipo de Decisão Judicial 10.3 'Alargamento' das Hipóteses de Oponibilidade de Embargos de Declaração 10.4 Prequestionamento 10.5 Ratificação de Recurso Excepcional 10.6 Apenamento pelo Uso de Embargos de Declaração Manifestamente Protelatórios 10.7 do Efeito Suspensivo 11. Breve Fechamento; 12. Referências Bibliográficas. 
Revista Eletrônica de Direito Processual - REDP.

Rio de Janeiro. Ano 10. Volume 17. Número 2. Julho a Dezembro de 2016

Periódico Semestral da Pós-Graduação Stricto Sensu em Direito Processual da UERJ

Patrono: José Carlos Barbosa Moreira. ISSN 1982-7636. pp. 579-622

www.redp.uerj.br

\section{DO OBJETO DO TRABALHO}

O ensaio tem o olhar fixado no manejo dos embargos de declaração no Direito Eleitoral brasileiro ${ }^{2}$, tema pouco tratado pela doutrina especializada. À vista disso, será feita uma exposição quanto aos aspectos fundamentais dessa figura processual. Partindo dessas explicações preliminares, esse apontará as peculiaridades dos embargos de declaração no âmbito do processo eleitoral e traçará um quadro sobre as mudanças legislativas e jurisprudenciais pertinentes à essa matéria.

Nada obstante a aplicação do Código de Processo Civil - de forma subsidiária no processo eleitoral, as já aludidas particularidades merecem ser ressaltadas nos embargos de declaração no campo do direito eleitoral, já que nem sempre há perfeita identidade entre a tal legislação extravagante com a codificação processual civil. Some-se ainda o fato de que os princípios do "Direito Processual Eleitoral” criam, em certa medida, ambiente para que algumas interpretações acerca do instituto apresentem colorido diferenciado ao que ocorre ordinariamente no Direito Processual Civil (e em outros ambientes especiais, como o Processo do Trabalho, por exemplo). Essas dessemelhanças entre os textos processuais serão denunciadas ao longo desse trabalho como um fator de desarmonia no ordenamento jurídico pátrio.

O texto também se justifica se lançarmos nossos olhos para o "novo" Código de Processo Civil (Lei 13.105/2015), eis que há mudanças em relação ao texto da codificação de 1973 e suas posteriores reformas.

Esse novo texto legal alterou a redação do artigo 275 do Código Eleitoral, dispositivo que passou incólume pelas legislações processuais pretéritas, e, assim, trouxe um novo padrão a oposição dos aclaratórios mediante o processo eleitoral. O novo padrão

\footnotetext{
${ }^{2}$ Uma primeira versão do presente estudo foi publicada inicialmente com os olhos no texto do projeto do novo CPC, versão Câmara dos Deputados (MAZZEI, Rodrigo. Embargos de declaração no processo eleitoral: peculiaridades e breve análise frente ao projeto de "Novo" Código de Processo Civil. Revista Forense, v. 417, p. 295-377). O trabalho acadêmico foi atualizado e reescrito em alguns trechos, especialmente para compor a presente obra e está ligado a uma sequência de textos que desenvolvemos acerca dos embargos de declaração.
} 
Revista Eletrônica de Direito Processual - REDP.

Rio de Janeiro. Ano 10. Volume 17. Número 2. Julho a Dezembro de 2016

Periódico Semestral da Pós-Graduação Stricto Sensu em Direito Processual da UERJ

Patrono: José Carlos Barbosa Moreira. ISSN 1982-7636. pp. 579-622

www.redp.uerj.br

se justifica pelo desejo do legislador infraconstitucional em atribuir certa unicidade ao sistema recursal.

Destarte, sem a intenção de esgotar o tema, o presente ensaio se debruçar sobre o microssistema do direito eleitoral em busca de elucidar as principais questões doutrinárias e jurisprudenciais pertinentes aos embargos de declaração na legislação eleitoral nacional. Toda essa analise terá um foco especial nos importantes impactos trazidos pelo novo CPC a essa temática.

\section{O CÓDIGO ELEITORAL COMO SUPERFÍCIE LEGAL DOS EMBARGOS DE DECLARAÇÃO NO PROCESSO ELEITORAL}

No Código Eleitoral (Lei 4.734 de 15 de julho de $1965^{3}$ ), há presença dos embargos de declaração no artigo 275 e seus parágrafos ${ }^{4}$.

\footnotetext{
${ }^{3}$ Registre-se que apesar do atual Código Eleitoral ser datado de 1965, a "Justiça Eleitoral Brasileira" foi criada muito antes, através do Decreto n 21.076 de 24 de fevereiro de 1932. Tal legislação está intimamente ligada aos atores da "Revolução de 30" (ou "Golpe de 30") e é fruto do trabalho de comissão nomeada por Maurício Cardoso (Ministro da Justiça da ocasião) e tendo Joaquim Francisco de Assis um dos seus mentores principais. O Código Eleitoral de 1932 tinha apego especial ao direito material, regulando temas de forma inovadora (como o alistamento dos eleitores e a instituição do voto feminino e do voto secreto). Todavia, já é possível localizar na referida codificação questões atinentes à temática processual (ainda que de forma embrionária), como era o caso dos recursos (artigos 103-106), cuja regulação era bem simples (e não previa instituto semelhante aos embargos de declaração). O Código Eleitoral de 1932, embora mantido em pontos capitais, foi substituído em 1935, com a promulgação do segundo Código Eleitoral: Lei no 48 de 04 de maio de 1935 (curioso que a referida lei fala em 'modificação do Código Eleitoral', mas o seu artigo 217 indica a substituição de diplomas: 'Art. 217. Ficam revogadas todas as disposições concernentes á materia eleitoral, mantidos, entretanto, os cargos e respectivos vencimentos até hoje legalmente creados, desde que não prejudicados por dispositivos deste Código'). O diploma de 1935 tratava os recursos de forma mais complexa (artigos 171-182), mas não dispunha sobre os embargos de declaração. Com o "Estado Novo" (1937-1945), a justiça eleitoral foi extinta e somente após a edição do Decreto-Lei n. ${ }^{0}$ 7.586, de 28-05-1945 (que restabeleceu a Justiça Eleitoral) que se retomou a construção de superfície legal para regular o "processo eleitoral" e, via de talante, os recursos eleitorais. Mesmo que timidamente, os embargos de declaração estão previstos Decreto-Lei . $^{\mathbf{7}} 7.586 / 45$, ao se admitir o manejo de tal instituto contra as decisões do Tribunal Superior Eleitoral em 48 (quarenta e oito) horas, em possível influência do Código de Processo Civil de 1939 (que já sistematizava os embargos de declaração com recurso - artigos 808, inciso V; 839-840; 862). Confira o dispositivo do Decreto-Lei n. ${ }^{0}$ 7.586/45: Art. 122. São definitivas as decisões proferidas pelo Tribunal Superior, cabendo apenas embargos de declaração dentro de 48 horas. Em seqüência, o processo eleitoral passa a ser regulado pela Lei n. ${ }^{\circ}$ 1.164, de 24-07-1950 (que institui um novo Código Eleitoral), tendo tal diploma tratado dos recursos com algum destaque (artigos 152-174), fazendo menção expressa aos embargos de declaração (art. 165 - Salvo os recursos constitucionais, o acórdão só poderá ser atacado por embargos de declaração oferecidos nas 48 horas seguintes publicação, e somente quando houver omissão, obscuridade ou contradição nos seus têrmos, ou quando não corresponder à decisão. Parágrafo único. Os embargos de declaração serão opostos em petição fundamentada dirigida ao relator, que os apresentará em mesa na primeira sessão). Finalmente, através da Lei no 4.373, de 15 de julho de 1965 (ou seja, durante o período do
} 
Revista Eletrônica de Direito Processual - REDP.

Rio de Janeiro. Ano 10. Volume 17. Número 2. Julho a Dezembro de 2016

Periódico Semestral da Pós-Graduação Stricto Sensu em Direito Processual da UERJ

Patrono: José Carlos Barbosa Moreira. ISSN 1982-7636. pp. 579-622

www.redp.uerj.br

Vale salientar que a redação do referido artigo não foi alterada desde a edição da citada codificação eleitoral, situação que deve ser observada, até mesmo para se aferir os pontos de contato e divergência com os Códigos de Processo Civil de 1939, 1973. É que o Código Eleitoral surge no hiato de tais diplomas, tal como se deu com a legislação penal codificada (Decreto 3.689 de 13 de outubro de 1941), apesar de ser mais tardio ${ }^{5}$. Quanto ao atual diploma processual civil, reservemos o ultimo capitulo desse artigo para as observações referentes às suas inovações técnicas e jurídicas.

O fato acima colocado em destaque é interessante, pois o Código Eleitoral tratava da dúvida como hipótese de oponibilidade dos embargos de declaração, diferentemente da codificação processual civil de 1939, mas semelhante ao original do texto codificado de $1973^{6}$. Todavia, de outra banda, trabalhava com a idéia de apenamento dos embargos de declaração manifestamente protelatórios, em semelhança ao que consta no Código de Processo Civil de 1939, afastando-se do disposto no diploma de 1973 (que opta pela multa pecuniária; postura adotada, também, pelo CPC de 2015).

Há, ainda, peculiaridade acerca do prazo de 03 (três) dias para o manejo dos embargos de declaração, prazo este sem eco em qualquer das três codificações (1939, 1973

Regime Militar), que foi apresentado o texto que hoje é tratado como Código Eleitoral e que será o eixo legal do nosso trabalho.

${ }^{4}$ Artigo 275. São admissíveis embargos de declaração: I - quando há no acórdão obscuridade, dúvida ou contradição; II - quando fôr omitido ponto sôbre que devia pronunciar-se o Tribunal. $\S 1^{\circ}$ Os embargos serão opostos dentro em 3 (três) dias da data da publicação do acórdão, em petição dirigida ao relator, na qual será indicado o ponto obscuro, duvidoso, contraditório ou omisso. $\S 2^{\circ} \mathrm{O}$ relator porá os embargos em mesa para julgamento, na primeira sessão seguinte proferindo o seu voto. $\S 3^{\circ}$ Vencido o relator, outro será designado para lavrar o acórdão. $\S 4^{\circ}$ Os embargos de declaração suspendem o prazo para a interposição de outros recursos, salvo se manifestamente protelatórios e assim declarados na decisão que os rejeitar.

${ }^{5}$ Os embargos de declaração no Processo Penal serão objeto de ensaio próprio. De toda sorte, o tema foi alvo de análise na nossa tese de doutoramento, fixando-se o estudo não apenas na suas peculiaridades, mas na forma assistêmica que atualmente estão postados na legislação processual e, inclusive, nos trabalhos legislativos de reforma para um "novo" Código de Processo Penal. Confira-se: MAZZEI, Rodrigo Reis. Embargos de Declaração: Recurso de saneamento com função constitucional. FADISP, Orientação Eduardo Arruda Alvim, 2012, p. 184-206.

${ }^{6}$ Não se pode esquecer que o Código de Processo Penal (artigos 382, 619 e 620) prevê que a decisão ambígua pode ser desafiada por embargos de declaração, situação que permite florescer entendimento de que naquele texto legal há espaço para manejo de embargos declaratórios para o caso de dúvida objetiva (caso esta seja resultante da decisão ambígua). Confira-se: Décio Lencioni Machado, Cinthia Nunes Vieira, Narcelo Felca e Naul Luiz Felca (Recursos no processo penal: teoria e prática. São Paulo: Editora Verbatim, 2010, p. 66), Sergio Ricardo de Souza e William Silva (Manual de processo penal constitucional: pós reforma de 2008. Rio de Janeiro: Forense, 2008, p. 601). 
Revista Eletrônica de Direito Processual - REDP.

Rio de Janeiro. Ano 10. Volume 17. Número 2. Julho a Dezembro de 2016

Periódico Semestral da Pós-Graduação Stricto Sensu em Direito Processual da UERJ

Patrono: José Carlos Barbosa Moreira. ISSN 1982-7636. pp. 579-622

www.redp.uerj.br

e 2015), bem assim na legislação especial que trata dos embargos de declaração para outros microssistemas ${ }^{7}{ }^{8}$.

Destaque-se que há previsão dos embargos de declaração no Regimento Interno do Tribunal Superior Eleitoral (Resolução $\mathrm{n}^{\circ}$ 4.510, de 29 de setembro de 1952). Consoante artigo $26^{9}$ de tal norma regimental, percebe-se a diferença redacional em relação ao disposto no Código Eleitoral, notadamente quanto ao prazo para o aviamento [48 (quarenta e oito horas)] e às hipóteses de oponibilidade (não consta a dúvida).

Fique bem claro que, desde já, que o novo CPC altera o quadro primitivo do Código Eleitoral. Isso porque, em seu art. 1.067, o CPC 2015 altera - de forma expressa a redação de raiz do art. 275 da legislação eleitoral em voga. Tal fato, consoante será visto ao longo do texto, causa mudanças em pontos relevantes da oponibilidade dos embargos de declaração no processo eleitoral.

\section{PRAZO PARA MANEJO DOS EMBARGOS DE DECLARAÇÃO}

$\mathrm{O} \S 1^{\circ}$ do artigo 275 do Código Eleitoral indica que o prazo para aviamento dos embargos de declaração é de 03 (três) dias da data da publicação (ciência) da decisão a ser

\footnotetext{
${ }^{7}$ Por exemplo, a Consolidação das Leis do Trabalho (CLT) - através da Lei 9.957 de 12 de janeiro de 2000, passou a regular os embargos de declaração no corpo da CLT, através do artigo 897-A, sendo ali fixado o prazo de 05 (cinco) dias para o manejo do instituto. Em outro exemplo marcante, no ambiente da Lei 9.099/95, o prazo para uso dos embargos de declaração nos Juizados Especiais é de 05 (cinco) dias a contar da ciência da decisão, consoante artigos 49 (parte cível) e $83, \S 1^{\circ}$ (parte criminal), ou seja, pouco importa a matéria (cível ou penal), naquele ambiente processual o prazo para postulação via embargos declaratórios será de 05 (cinco) dias. Merece também destaque o artigo 30 da Lei 9.307/96 (que trata de arbitragem), uma vez que tal legislação, embora não faça menção expressa aos embargos de declaração, permite - a pedido da parte - a correção de erro material da sentença arbitral, assim como o esclarecimento de obscuridade, dúvida ou contradição da sentença arbitral e o pronunciamento sobre ponto omitido a respeito do qual devia manifestar-se a decisão, postulação esta que deve ser apresentada pela parte em 05 (cinco) dias.

${ }^{8}$ Sobre microssistemas, especialmente sua relação com as codificações e a Constituição Federal, confira-se nosso texto sobre o assunto: O Código Civil de 2002 e a sua interação com os Microssistemas e a Constituição Federal. Revista da Faculdade Autônoma de Direito, v. 1, p. 245-278, 2011. Ainda sobre microssistemas, com olhos mais voltados para o direito processual, produzimos o seguinte texto: A ação popular e o microssistema da tutela coletiva. In: Luiz Manoel Gomes Junior; Ronaldo Fenelon Santos Filho. (Org.). Ação popular: aspectos relevantes e controvertidos. São Paulo: RCS, 2006, p. 397-428.

${ }^{9}$ Artigo 26. Salvo os recursos para o Supremo Tribunal Federal, o acórdão só poderá ser atacado por embargos de declaração oferecidos nas 48 horas seguintes à publicação e somente quando houver omissão, obscuridade ou contradição nos seus termos ou quando não corresponder à decisão. $\S 1^{\circ}$ Os embargos serão opostos em petição fundamentada dirigida ao relator, que os apresentará em mesa na primeira sessão. § $2^{\circ} \mathrm{O}$ prazo para os recursos para o Supremo Tribunal e embargos de declaração contar-se-á da data da publicação das conclusões da decisão no Diário da Justiça.
} 
Revista Eletrônica de Direito Processual - REDP.

Rio de Janeiro. Ano 10. Volume 17. Número 2. Julho a Dezembro de 2016

Periódico Semestral da Pós-Graduação Stricto Sensu em Direito Processual da UERJ

Patrono: José Carlos Barbosa Moreira. ISSN 1982-7636. pp. 579-622

www.redp.uerj.br

embargada ${ }^{10}$, no que - como dito - se distancia da legislação processual cível e penal (e de

outras leis de índole especial).

Destaque-se, contudo, que há entendimento no sentido de que o prazo do artigo 275 somente se aplica quando o foco for matéria cível eleitoral. Caso a decisão envolva matéria criminal eleitoral, deverá ser observado o prazo de 02 (dois dias) do Código de Processo Penal (artigo 619). ${ }^{11}$ Tal posicionamento está firmado na aplicação do artigo 364 do Código Eleitoral ${ }^{12}$, que prevê a aplicação supletiva do Código de Processo Penal nas questões afetas aos crimes eleitorais.

O entendimento em voga, ao menos na nossa visão, não é correto. Isso porque o alcance do artigo 364 não é ilimitado e somente deve ser trazida matéria da legislação processual penal em caso de omissão do Código Eleitoral. Não é o caso, pois o $\S 1^{\circ}$ do artigo 275 não faz discriminação alguma acerca da questão discutida, de modo que o prazo dos embargos de declaração na justiça eleitoral - qualquer que seja o tema - deve ser uniforme, respeitando sempre 03 (três) dias. Pensar diferente cria detalhamento que conspira contra a segurança jurídica na aplicação da norma e, além disso, esvazia o Código Eleitoral como norma de base para as questões eleitorais, passando a legislação supletiva a ter mais força, sem que haja justificativa plausível para tal. ${ }^{13}$

10 Armando Antonio Sobreiro Neto, ao analisar o artigo 258 do Código Eleitoral (que trata dos prazos recursais de maneira geral), afirma que: "Embora o dispositivo mencione que o prazo flui a contar da publicação do ato, resolução ou despacho, os prazos recursais devem ser contados: a) matéria eleitoral de natureza civil - [CPC de 1973], art. 184; b) matéria eleitoral penal - CPP, art. 798. Se a lei eleitoral dispuser de modo diverso, para uma determinada eleição ou ato processual (ex. LC 64/90, art. 16), ou, ainda, Resolução do TSE venha regular de modo especial, deverão ser observadas as regras especiais. Quando o prazo for de direito material, em sede criminal, conta-se na forma do art. 10 do Código Penal, salvo se disposto diferentemente na norma especial" (Direito eleitoral. $3^{a}$ ed.. Curitiba: Juruá, 2004, p. 300). Sobre prazo dos embargos de declaração especificamente, confira-se: Tito Costa (Recursos em Matéria Eleitoral. 9. ed. rev., atual. e ampl. São Paulo: Revista dos Tribunais, 2010. p. 113).

${ }^{11}$ No sentido: Joel José Cândido (Direito eleitoral brasileiro. 6. ed.. São Paulo: Edipro, 1996. p. 223-224).

${ }^{12}$ Artigo 364. No processo e julgamento dos crimes eleitorais e dos comuns que lhes forem conexos, assim como nos recursos e na execução, que lhes digam respeito, aplicar-se-á, como lei subsidiária ou supletiva, o Código de Processo Penal.

${ }^{13}$ A reforçar nosso pensar, vale registrar que o Tribunal Superior Eleitoral já decidiu pela aplicação do prazo do $\S 1^{\circ}$ do artigo 275 em qualquer questão eleitoral, alcançando as matérias de caráter penal, confira-se: “EMBARGOS DECLARATÓRIOS EM MATÉRIA PENAL ELEITORAL. PRAZO DE TRÊS DIAS PARA A INTERPOSIÇÃO. NORMA ESPECÍFICA DO CÓDIGO ELEITORAL (ART. $275, \S 1^{\circ}$ ). INAPLICABILIDADE DO PRAZO PREVISTO NO CÓDIGO DE PROCESSO PENAL. Recurso especial conhecido e provido para afastar a intempestividade proclamada pela egrégia Corte Regional" (TST, RECURSO ESPECIAL ELEITORAL n 25563, Acórdão de 27/04/2006, Relator Ministro MARCELO 
Revista Eletrônica de Direito Processual - REDP.

Rio de Janeiro. Ano 10. Volume 17. Número 2. Julho a Dezembro de 2016

Periódico Semestral da Pós-Graduação Stricto Sensu em Direito Processual da UERJ

Patrono: José Carlos Barbosa Moreira. ISSN 1982-7636. pp. 579-622

www.redp.uerj.br

De toda sorte, considerando que se trata de questão que - no mínimo - inspira dúvida objetiva, aplicando-se os cânones do processo penal, embargos declaratórios devem ser recebidos em 03 (três) dias nas questões envolvendo os crimes eleitorais, até mesmo para prestigiar o direito à ampla defesa.

Há um detalhe interessante que deve ser consignado. Com efeito, nos diplomas legais que os prevêem, os embargos de declaração normalmente possuem prazo diferenciado dos demais recursos. Contudo, no Código Eleitoral tal não acontece, pois o prazo de 03 (três) dias não é específico para os embargos declaratórios, sendo, em verdade, aplicável a todos os vetores recursais, nos termos do artigo 258 da referida norma. ${ }^{14}$

A observação destacada, a qual nos permite dizer que o processo eleitoral é extremamente dinâmico e, como tal, possui prazos mais exíguos ${ }^{15}$, não está totalmente afinada em relação aos embargos de declaração. Ora, quando promulgado o Código Eleitoral, o prazo de 03 (três) dias era superior ao prazo de 48 (quarenta e oito) horas do Código de Processo Civil de 1939, bem assim do Código de Processo Penal de 1941. Atualmente, bem é verdade, o prazo previsto no $§ 1^{\circ}$ do artigo 275 do Código Eleitoral só não é mais curto do que o disposto na codificação processual penal (artigo 619), já que, em regra, nos outros diplomas, os embargos de declaração serão apresentados em 05 (cinco) dias. $^{16}$

Contudo, nem sempre o prazo do Código Eleitoral de 03 (três) dias será o aplicável aos embargos de declaração.

HENRIQUES RIBEIRO DE OLIVEIRA, Publicação: DJ - Diário de Justiça, Data 02/06/2006, p. 99). Vale consulta do teor completo do acórdão (doze páginas), diante do debate de alto nível ocorrido para a fixação do precedente, que conta com votos divergentes sustentando a aplicação do artigo 364 do Código Eleitoral.

14 Art. 258. Sempre que a lei não fixar prazo especial, o recurso deverá ser interposto em três dias da publicação do ato, resolução ou despacho.

${ }^{15}$ No sentido: Torquarto Jardim (Introdução ao direito eleitoral positivo. Brasília: Brasília Jurídica, 1994, p. 78) e Christopher Rezende Guerra Aguiar (Recursos na Justiça Eleitoral. In Atualidades do Processo Civil. Arruda Alvim e Eduardo Arruda Alvim (Coords.). Vol. I. Curitiba: Juruá Editora, 2006. p. 305).

16 Como é o caso dos artigos 897-A da CLT, 49 e 83 da Lei 9.099/95 e 30 da Lei 9.307/96. 
Revista Eletrônica de Direito Processual - REDP.

Rio de Janeiro. Ano 10. Volume 17. Número 2. Julho a Dezembro de 2016

Periódico Semestral da Pós-Graduação Stricto Sensu em Direito Processual da UERJ

Patrono: José Carlos Barbosa Moreira. ISSN 1982-7636. pp. 579-622

wWW.redp.uerj.br

Diante do emaranhado de leis que gravitam e envolvem o direito eleitoral (com a

formação de microssistema extravagante, isto é, com regramentos próprios tanto de direito material quanto processual), é de bom alvitre que aquele que desejar apresentar embargos de declaração não seja surpreendido com decisão imputando intempestividade de peça processual apresentada no prazo de 03 (três) dias ditado pelo Código Eleitoral. Isso porque, prevalece o entendimento de que, como o prazo dos embargos de declaração é comum aos demais recursos no Código Eleitoral, os prazos recursais fixados em leis especiais para os recursos eleitorais (num sentido genérico) serão também aplicados aos embargos de declaração.

Com outras palavras, no processo eleitoral os prazos para recursos são fixados em regra - de modo geral para todas as espécies recursais, não distanciando das regulações os embargos de declaração, mesmo que a lei não diga de forma expressa que está açambarcando estes.

Exemplo que pode ilustrar a questão se infere do entendimento firmado no sentido de que, no ambiente da Lei 9.504, de 30 de setembro de 1997, que estabeleceu normas para as eleições, não há previsão expressa para o manejo de embargos de declaração. Entretanto, firmou-se posição de que, em razão do $\S 8^{\circ}$ do artigo 96 da citada lei ${ }^{17}$, o prazo para os embargos de declaração, naquele ambiente legal, seria de 24 (vinte e quatro) horas, ou seja, remetendo a regra geral de todos os recursos prevista em tal diploma para os embargos declaratórios. ${ }^{18}$

\footnotetext{
${ }^{17}$ Art. 96. Salvo disposições específicas em contrário desta Lei, as reclamações ou representações relativas ao seu descumprimento podem ser feitas por qualquer partido político, coligação ou candidato, e devem dirigirse: I - aos Juízes Eleitorais, nas eleições municipais; II - aos Tribunais Regionais Eleitorais, nas eleições federais, estaduais e distritais; III - ao Tribunal Superior Eleitoral, na eleição presidencial (...). $\$ 8^{\circ}$ Quando cabível recurso contra a decisão, este deverá ser apresentado no prazo de vinte e quatro horas da publicação da decisão em cartório ou sessão, assegurado ao recorrido o oferecimento de contra-razões, em igual prazo, a contar da sua notificação.

${ }^{18}$ Confira-se: “(..). EMBARGOS DECLARATÓRIOS. INSTÂNCIA ORDINÁRIA. PRAZO RECURSAL. 24 HORAS. INTEMPESTIVIDADE. (...). O prazo recursal para o oferecimento de embargos de declaração, em instância ordinária, nas representações relativas ao descumprimento da Lei no 9.504/97 é de 24 (vinte e quatro) horas. (...) Os embargos de declaração extemporâneos não interrompem o prazo para interposição do recurso especial eleitoral. Logo, padece de intempestividade reflexa o apelo especial interposto pelos agravantes" (TSE, Agravo Regimental em Agravo de Instrumento n 10723, Acórdão de 20/05/2010, Relator Min. ALDIR GUIMARÃES PASSARINHO JUNIOR, DJE 03/08/2010, p. 263); “(...) Visando uniformizar os prazos processuais nas instâncias regionais, além de imprimir maior celeridade ao processo, a
} 
Revista Eletrônica de Direito Processual - REDP.

Rio de Janeiro. Ano 10. Volume 17. Número 2. Julho a Dezembro de 2016

Periódico Semestral da Pós-Graduação Stricto Sensu em Direito Processual da UERJ

Patrono: José Carlos Barbosa Moreira. ISSN 1982-7636. pp. 579-622

www.redp.uerj.br

Portanto, a simetria dos prazos dos embargos de declaração (artigo 275, $\S 1^{\circ}$ ) com os demais vetores recursais (artigo 256) cria ambiente especial de similitude de prazos de manejo, que deve ser observada com atenção pelo intérprete. Em suma, o recorrente deve estar atento ao fato de que o prazo é uniforme para todas as figuras recursais (inclusive para os embargos declaração), somente ocorrendo exceção se o legislador expressamente discriminar a hipótese.

Ainda no espectro dos prazos para aviamento dos embargos de declaração, há uma situação desconfortável - aparente antinomia - entre o Código Eleitoral e o Regimento Interno do Tribunal Superior Eleitoral, pois este último prevê, em seu artigo 26, que os embargos de declaração devem ser aviados em 48 (quarenta e oito) horas, afastando-se, assim, do prazo vulgar de 03 (três) dias previsto no Código Eleitoral. Ainda que abstraindo a questão da (im)possibilidade das Cortes Superiores terem espaço para legislar acerca de direito processual ${ }^{19}$, duas interpretações emergem para resolver o conflito.

jurisprudência pacífica do e. TSE tem decidido que o prazo para recurso contra acórdão regional em representação, inclusive nos embargos de declaração, segue o disposto no art. 96, § $8^{\circ}$, da Lei $n^{\circ}$ 9.504/97. (REspe $n^{\circ}$ 28.209/PA, Rel. Min. Caputo Bastos, DJ de 14.8.2007; REspe no 26.904/TO, Rel. Min. Cezar Peluso, DJ de 12.12.2007; EDcl-RO n ${ }^{\circ} 1.494 / \mathrm{SE}$, de minha relatoria, redator para o acórdão Min. Marcelo Ribeiro, DJE de 5.12.2008). (...) A alegada violação a dispositivo de regimento interno de tribunal regional, em sede de recurso especial, encontra óbice nas Súmulas nos 399 e 280 do c. STF. Nesse sentido também, há reiterada jurisprudência do e. STJ, uma vez que a norma regimental de tribunal local não se enquadra no conceito de lei federal: REsp 766187/BA, Rel. Min. Luiz Fux, DJ 31.5.2007; REsp 88993/DF, Rel. Min. Edson Vidigal, DJ de 10.6.1996; AgRg no Ag 325695/MT, Rel. Min. Barros Monteiro, DJ de 31.3.2003; AgRg no Ag 641363/RS, Rel. Min. Luiz Fux, DJ de 13.2.2006; REsp 298439/RS, Rel. Min. Gilson Dipp, DJ de 10.6.2002. 3. Agravo regimental não provido" (TSE, Agravo Regimental em Agravo de Instrumento ${ }^{\circ}$ 11241, Acórdão de 18/06/2009, Relator Min. FELIX FISCHER, DJE 01/09/2009, p. 17).

19 O artigo 22, I, da Constituição Federal de 1988 confere à União Federal a competência exclusiva para se legislar sobre Direito Processual, situação que repudia, na nossa opinião, os regimentos internos como diplomas capazes de criar e regulamentar figuras processuais, como os recursos. No sentido: “(...) Pelo princípio da taxatividade, somente são recursos aqueles previstos na lei federal, em "numerus clausus". Assim, norma regimental de tribunal não pode instituir recurso ainda não previsto no ordenamento positivo do País, sob pena de violação do art. 22, I, da Constituição, que trata da competência privativa da União para legislar sobre direito processual. (...) Na esteira de entendimento doutrinário, com precedente nesta Corte (RMS 7823-RS), aplica-se o art. 39 da Li 8038/90, que prevê o cabimento de agravo interno contra decisão de relator, a todos os tribunais" (STJ, AgRg no RMS 9.395/BA, Rel. Ministro SÁLVIO DE FIGUEIREDO TEIXEIRA, QUARTA TURMA, j. 01/09/1998, DJ 14/12/1998, p. 241). Na doutrina, analisando como os Tribunais invadem tema que, a priori, seriam reservados a legislação federal, vale conferir Daniel Ustárroz e Sergio Gilberto Porto (Manual dos recursos cíveis. $3^{\text {a }}$. ed. Porto Alegre: Livraria do Advogado, 2011, p. 59$61)$. 
Revista Eletrônica de Direito Processual - REDP.

Rio de Janeiro. Ano 10. Volume 17. Número 2. Julho a Dezembro de 2016

Periódico Semestral da Pós-Graduação Stricto Sensu em Direito Processual da UERJ

Patrono: José Carlos Barbosa Moreira. ISSN 1982-7636. pp. 579-622

wWW.redp.uerj.br

Uma linha interpretativa que pode ser feita é a da prevalência da regra especial (regimento interno) sobre a norma geral (codificação), situação que já ocorre no espaço do processo eleitoral em que se aplica a Lei 9.504/1997 (como vimos anteriormente). Ademais, em reforço a tal idéia, não se pode esquecer que o Supremo Tribunal Federal vem entendendo que o artigo $337, \S 1^{\circ}$ de seu regimento interno - ao fixar o prazo de cinco dias para o aviamento dos embargos de declaração - prevalece sobre o disposto no artigo 619 do Código de Processo Penal, e, por tal passo, não aplica o prazo previsto na codificação para o manejo dos embargos (dois dias). ${ }^{20}$

Seguindo outra linha de interpretação para resolver a antinomia, é possível se dizer que, como o Regimento Interno do Tribunal Superior Eleitoral (Resolução no 4.510, de 29 de setembro de 1952) é anterior ao Código Eleitoral (Lei n ${ }^{\circ} 4.737$ de 15 de julho de 1965), o segundo texto deve prevalecer no que tange à mudança implementada para o prazo dos embargos de declaração. Em reforço a esta tese, diz-se que a prevalência da regra regimental é contrária à diretriz de uniformidade dos prazos aplicáveis ao processo eleitoral que, como vimos, inclui os embargos de declaração.

Do quadro exposto acima, pensamos que a melhor solução está na aplicação do prazo de 03 (três) dias do Código Eleitoral e os nossos motivos são variados. O prazo de 48 (quarenta e oito) horas do Regimento se finca na realidade do Código de Processo Civil de 1939, vigente à época em que fora editado o texto regimental. A unificação dos prazos recursais - com a inclusão dos embargos de declaração na diretriz - é uma medida salutar que cria segurança jurídica ao jurisdicionado e permite a aplicação coerente do sistema recursal eleitoral. Haveria, a prevalecer o texto regimental datado de 1952, uma involuntária corrosão de princípio (salutar) do processo eleitoral.

Não suficiente, afigura-nos inaplicável o argumento de que o Supremo Tribunal Federal fez prevalecer seu regimento interno sobre o Código de Processo Penal. De plano, há de se notar que a alteração do prazo para o manejo dos embargos de declaração para 05 (cinco) dias, no texto regimental da Corte Suprema, deu-se em $1970^{21}$, por meio de seu

20 Confira-se: STF, EDcl no HC 82.214-2 DF, Relator Ministro CARLOS VELLOSO, DJU 22.11.2002; STF, AP 361 ED, Relator Ministro MARCO AURÉLIO, Tribunal Pleno, j. 03/03/2005, DJ 06-05-2005, p. 07.

${ }^{21}$ Regimento Interno publicado no Diário da Justiça no dia 04 de setembro de 1970. Houve a substituição do regimento anterior, datado de 1940 (DJ 28.02.1940, p. 1239-1253) que previa o prazo de 48 (quarenta e oito) horas para apresentação dos embargos de declaração (artigo 201). 
Revista Eletrônica de Direito Processual - REDP.

Rio de Janeiro. Ano 10. Volume 17. Número 2. Julho a Dezembro de 2016

Periódico Semestral da Pós-Graduação Stricto Sensu em Direito Processual da UERJ

Patrono: José Carlos Barbosa Moreira. ISSN 1982-7636. pp. 579-622

www.redp.uerj.br

artigo $314, \S 1^{\text {o22 }}$, ou seja, a mudança é posterior à promulgação do CPP (Decreto-lei 3.689

de 03 de outubro de 1941). Assim, a regra posterior prevalece em relação à anterior, em situação diversa ao Código Eleitoral em comparação ao Regimento Interno do Tribunal Superior Eleitoral, pois o diploma codificado é posterior ao texto regimental. Além disso, a posição do Supremo Tribunal Federal - com o dilargamento do prazo -, por ser mais benéfica ao recorrente, não cria embaraço fatal à segurança jurídica, já que não há trancamento de recurso por intempestividade.

Por tais razões, o disposto no artigo 26 do Regimento Interno do Tribunal Superior Eleitoral acerca do prazo de manejo dos embargos de declaração - sob nossa ótica - foi superado pelo disposto no $\S 1^{\circ}$ do artigo 275 do Código Eleitoral, ocorrendo situação invertida em relação ao texto regimental do Supremo Tribunal Federal, que é posterior ao Código de Processo Penal.

Por fim, não se pode deixar de anotar que a regra do artigo 191 do Código de Processo Civil de 1973 não vinha sendo aplicada no âmbito do processo eleitoral, eis que tal dispositivo, segundo a jurisprudência dominante, viola a diretriz da celeridade da Justiça Eleitoral. ${ }^{23}$ Essa inaplicabilidade não será alterada pelo CPC de 2015, já que este, em seu artigo 229, repete a mesma regra processual.

\section{NATUREZA JURÍDICA}

Não é novo o debate sobre a natureza jurídica dos embargos de declaração. Há posição de que os embargos de declaração não podem ser tratados como recurso, devendo ser vistos como incidente de aperfeiçoamento ou de complementação do julgado ${ }^{24} \mathrm{e}$, de

\footnotetext{
${ }^{22}$ A regra foi prestigiada no regimento atual desde sua versão original (DJ 27/10/1980), consoante se infere do artigo $337, \S 1^{\circ}$.

${ }^{23}$ No sentido: "Na linha da jurisprudência deste Tribunal, a contagem de prazo em dobro, prevista no art. 191 do CPC, não se aplica aos feitos eleitorais, que tratam de litisconsortes com diferentes procuradores" (TSE, AgR-REspe $n^{\circ}$ 36693, Relator Ministro ARNALDO VERSIANI LEITE SOARES, Diário da Justiça Eletrônico, Tomo 87, Data 10/05/2011, p. 460. Igual sentido: TSE, AgR-AI no 57839, Relator Ministro MARCELO HENRIQUES RIBEIRO DE OLIVEIRA, DJE - Diário da Justiça Eletrônico, Data 03/03/2011, p. 20; TSE, ARO n ${ }^{\circ}$ 905, Relator Ministro JOSÉ GERARDO GROSSI, DJ - Diário de Justiça, Data 23/08/2006, p. 108).

${ }^{24}$ Há autores de peso que defendem a tese de os embargos de declaração não serem recurso, como é o caso de Sérgio Bermudes (Comentários ao Código de Processo Civil, 2. ${ }^{a}$ ed., São Paulo: Revista dos Tribunais, vol. 07, ano, 1975, p. 207-210), que afirma: "Mero incidente, destinado ao aperfeiçoamento da forma pela
} 
Revista Eletrônica de Direito Processual - REDP.

Rio de Janeiro. Ano 10. Volume 17. Número 2. Julho a Dezembro de 2016

Periódico Semestral da Pós-Graduação Stricto Sensu em Direito Processual da UERJ

Patrono: José Carlos Barbosa Moreira. ISSN 1982-7636. pp. 579-622

www.redp.uerj.br

forma divergente, há corrente que defende a natureza recursal dos embargos de declaração, perfilando entendimento de que estes devem ser vistos como espécie de recurso. ${ }^{25}{ }^{26}$

Discussão próxima se encontra firmada nos trabalhos que tratam do processo eleitoral $^{27}$, ainda que com menor intensidade que em outros ramos de processo especializado. A maioria dos autores trata do instituto como recurso, como é o caso de CHRISTOPHER REZENDE GUERRA AGUIAR ${ }^{28}{ }^{29} \mathrm{e}$, mesmo os que não consideram os

qual a sentença se materializou, o embargos de declaração não constituem um recurso" (ob. cit, p.210). Rogério Lauria Tucci nega a natureza jurídica dos embargos de declaração como recurso por entender que é uma "providência destinada ao esclarecimento do julgado, equivalendo a correção que, por meio deles, se objetiva, à integração do ato decisório embargado. Por isso mesmo, aliás, é que não podem ser considerados como recurso, inobstante recente tendência doutrinária no sentido de atribui-lhes, em dadas circunstâncias, efeitos modificativos do decidido. Ostentam eles, na realidade, a natureza processual de incidente de complementação do julgado, cuja finalidade é a de aperfeiçoar formalmente a sentença ou acórdão embargado. E relacionam-se, destarte, mais com o conteúdo deste, e precipuamente, com o modo pelo qual é exprimido" (Curso de direito processual civil: processo de conhecimento. Volume III. São Paulo: Saraiva, 1989, 387-388). Confira-se ainda: Wellington Moreira Pimentel (Comentários ao código de processo civil. Volume III. São Paulo: Revista dos Tribunais, 1975, p. 540) Marcos Afonso Borges (Comentários ao código de processo civil. Volume II. São Paulo: LEUD, 1975, p. 263), Antonio Macedo Campos (Recursos no processo civil. São Paulo: Sugestões Literárias, 1980, p. 267), Antonio Cláudio da Costa Machado (A reforma do processo civil interpretada. $2^{a}$ edição. São Paulo: Saraiva, 1996, 88).

${ }^{25} \mathrm{Na}$ doutrina atual, entre vários, pode se citar no sentido: Eduardo Arruda Alvim (Direito processual civil. $2^{\mathrm{a}}$ ed.. São Paulo: Revista dos Tribunais, p. 829), Araken de Assis (Manual dos Recursos. 2. ed. rev. e ampl., São Paulo: Revista dos Tribunais, 2008, p. 590-591), Alexandre Freitas Câmara, (Lições de direito processual civil. Volume II. 10ª. ed.. Rio de Janeiro: Lumen Juris, 2005. p. 116-117), Ovídio A. Baptista da Silva (Curso de processo civil. Vol. I. 5a . ed. São Paulo: Revista dos Tribunais, 2001, p. 447), Nelson Rodrigues Neto (Recursos no processo civil. São Paulo: Dialética, 2004, p. 119-120), Antonio Carlos Matteis de Arruda (Recursos no processo civil: teoria geral e recursos em espécie. São Paulo: Editora Juarez de Oliveira, 2002, p. 209-210), Fredie Didier Jr. e Leonardo José Carneiro da Cunha (Curso de Direito Processual Civil: Meios de impugnação às decisões judiciais e processos nos tribunais. Volume 3. $7^{\text {a }}$. ed. Salvador: Editora Juspodivm, 2009. p. 183), José Carlos Barbosa Moreira (Comentários ao Código de Processo Civil. 9. ed. Rio de Janeiro: Forense, 2001. vol. V: arts. 476 a 565, p. 540), Flávio Cheim Jorge (Teoria geral dos recursos cíveis. $3^{\text {a }}$. ed. São Paulo: Revista dos Tribunais, 2007, p. 262) e Bernardo Pimentel Souza (Introdução aos Recursos Cíveis e à Ação Rescisória. 7. ed. São Paulo: Saraiva, 2010, p. 418-419).

${ }^{26}$ Há posição intermediária, considerando como recurso quando os embargos de declaração visam "a melhora da situação da parte, e não nas hipóteses clássicas do manejo dos embargos, as quais não se destinam, alterar a substância do julgado", conforme Daniel Ustárroz e Sergio Gilberto Porto (Manual dos recursos cíveis. 3a . ed. Porto Alegre: Livraria do Advogado, 2011, p. 197-198). Próximos: No sentido; Cândido Rangel Dinamarco (Nova era do processo civil. São Paulo: Malheiros, 2003, p. 178-288), Luis Guilherme Aidar Bondioli (Embargos de declaração. São Paulo: Saraiva, 2005. p. 55-73).

${ }^{27}$ Por exemplo, Fávila Ribeiro traz à discussão, apresentando as correntes sobre a natureza jurídica dos embargos de declaração (Direito Eleitoral. 5. ed. Rio de Janeiro: Forense, 2000. p. 583-584).

${ }^{28}$ Recursos na Justiça Eleitoral. In Atualidades do Processo Civil. Arruda Alvim e Eduardo Arruda Alvim (Coords.). Vol. I. Curitiba: Juruá Editora, 2006. p. 307-308.

${ }^{29}$ Parecendo adotar a mesma posição, por arrolar os embargos de declaração como recurso (ainda que sem fundamentação sobre a natureza jurídica), confira-se: Joel José Cândido (Direito eleitoral brasileiro. 6. ed. rev., ampl. e atual. São Paulo: Edipro, 1996. p. 222), Jair Eduardo Santana e Fabio Guimarães (Direito eleitoral resumido. Belo Horizonte: Inédita, 2000, p. 191), Antonio Carlos Pimentel Mello (Manual de 
Revista Eletrônica de Direito Processual - REDP.

Rio de Janeiro. Ano 10. Volume 17. Número 2. Julho a Dezembro de 2016

Periódico Semestral da Pós-Graduação Stricto Sensu em Direito Processual da UERJ

Patrono: José Carlos Barbosa Moreira. ISSN 1982-7636. pp. 579-622

www.redp.uerj.br

embargos de declaração como espécie recursal, como faz TITO COSTA ${ }^{30}{ }^{31}$, reconhecem

sua importância no sistema processual eleitoral.

Nossa posição é no sentido de que os embargos de declaração devem ser tratados como recurso, mas como uma espécie diferenciada: recurso de saneamento. ${ }^{32}$ Com efeito, os embargos de declaração desdobram o ato judicial em partes que, apesar de fisicamente separadas, coexistem como uma unidade, pois o segundo nasce para sanear o ato decisório embargado (e não para cassá-lo ou substituí-lo). Dessa forma, os embargos de declaração se nada de excepcional ocorrer - irão gerar decisão saneadora posteriormente agregada ao ato judicial embargado que, involuntariamente, foi acometido de omissão, contradição ou obscuridade. $^{33}$ Logo, o ato judicial derivado que nasce em decorrência dos embargos de declaração não tem natureza autônoma, sendo um complemento do primitivo. ${ }^{34}{ }^{35}$

A índole saneadora dos embargos de declaração fica nítida quando se examina conjuntamente os artigos 494 e 1.022 do CPC de 2015, os quais correspondem, respectivamente, aos artigos 463 e 535 do Código de Processo Civil de 1973. Isso porque,

direito eleitoral. Ibiraçu; Integral, 2002, p. 424-425) e Armando Antonio Sobreiro Neto (Direito eleitoral. $3^{\mathrm{a}}$ ed.. Curitiba: Juruá, 2004, p. 302-303).

${ }^{30}$ Recursos em Matéria Eleitoral. 9. ed. rev., atual. e ampl. São Paulo: Revista dos Tribunais, 2010. p. 110.

${ }^{31}$ Para Antônio Veloso Peleja Júnior e Fabrício Napoleão Teixeira Batista: "É tema polêmico a natureza jurídica dos Embargos. Em nosso entender, não se trata de recurso, mas da possibilidade de supressão de lacunas ante a obscuridade, dúvida ou omissão" (Direito Eleitoral: aspectos processuais - ações e recursos. $2^{\mathrm{a}}$ ed. Curitiba: Juruá, 2012, p. 548).

32 O tema é tratado com vagar e análise de diversos ângulos e desdobramentos na nossa tese de doutoramento: Embargos de Declaração: Recurso de saneamento com função constitucional. (FADISP, Orientação Eduardo Arruda Alvim, 2012).

${ }^{33}$ Segundo Vicente Miranda: "A finalidade do recurso de embargos não é alteração ou modificação do julgado. Não se pede sua reforma. O fim é o esclarecimento ou a complementação. Tal esclarecimento ou tal complementação, que se opera por via recursal, integra a anterior decisão embargada; dela faz parte; a ela se adiciona” (Embargos de Declaração no Processo Civil. São Paulo: Saraiva, 1990, p. 65).

${ }^{34}$ Muito comum é o "batismo" da fala judicial derivada de "despacho" ou de "decisão", pouco importando a natureza jurídica da diç̧ão judicante primitivamente embargada. A seguir o raciocínio de que o ato derivado - fruto da oposição dos declaratórios - é um complemento da anterior pronúncia judicial, o magistrado receptor dos declaratórios terá que analisar a natureza jurídica do seu ato judicial embargado e integrá-lo com novo ato judicial de mesma natureza. No mesmo sentido: Fredie Didier Jr. e Leonardo José Carneiro da Cunha (Curso de Direito Processual Civil: Meios de impugnação às decisões judiciais e processos nos tribunais. Volume 3. 7.ed. Salvador: Editora Juspodivm, 2009. p. 203-206).

${ }^{35}$ No sentido, vale conferir: Moacyr Amaral Santos (Comentários ao Código de Processo Civil. Volume IV. Rio de Janeiro: Editora Forense, 1975, p. 448), Pontes de Miranda (Comentários ao código de processo civil. Tomo VII. Rio de Janeiro: Forense, 1975, p. 428), Gabriel José de Rodrigues Rezende Filho (Curso de direito processual civil. Volume III. 5a . ed.. São Paulo: Saraiva, 1960, p.110-111), Alfredo de Araújo Lopes da Costa (Direito processual civil brasileiro. Volume III. $2^{\mathrm{a}}$ ed.. Rio de Janeiro: Forense, p. 314-315) e Ivan de Hugo Silva (Recursos no novo Código de processo civil. Rio de Janeiro: Forense, 1976, p. 296). 
Revista Eletrônica de Direito Processual - REDP.

Rio de Janeiro. Ano 10. Volume 17. Número 2. Julho a Dezembro de 2016

Periódico Semestral da Pós-Graduação Stricto Sensu em Direito Processual da UERJ

Patrono: José Carlos Barbosa Moreira. ISSN 1982-7636. pp. 579-622

www.redp.uerj.br

nos casos de erro material, o próprio julgador poderá sanear sua decisão,

independentemente de qualquer ato postulatório da parte. Assim, pode o julgador - mesmo sem provocação - corrigir inexatidões materiais ou erros de cálculo, ou seja, lançar (em novo ato judicial) capítulo retificador de dicção pretérita que irá absorver o ato de saneamento. No entanto, nos casos de omissão ${ }^{36}$, contradição ou obscuridade, o saneamento reclama postulação, ou seja, deverá ter requerimento específico em forma de embargos declaratórios.

Então, resumidamente, o legislador reservou no atual $\mathrm{CPC}$, assim como a legislação anterior, duas hipóteses de saneamento da decisão já proferida - sem que seja necessário remeter a labuta para outro órgão judicante -, quais sejam: (a) correção de erros materiais e de cálculos, imunes a qualquer tipo de preclusão e que não dependem de postulação das partes (artigo 463, I do CPC 73; 494, I do CPC 2015); (b) sanação de obscuridade, contradição e omissão, que depende de provocação das partes, via embargos de declaração. ${ }^{37}$. No caso do artigo 463, II do antigo diploma buzadiano, o aviamento dos embargos de declaração indicava a função clássica de recurso, eis que havia a postulação para correção de ato judicial decisório e, enquanto não ocorria o julgamento, a preclusão (e seus efeitos inerentes e sequenciais) estaria obstada. Aguardava-se, pois, a decisão derivada, que estaria vinculada à decisão primitiva (ato embargado), pois a dicção que surgia pela oposição dos embargos de declaração não tinha o condão de tomar (ao menos ordinariamente) o espaço da fala matriz.

\footnotetext{
${ }^{36}$ A correção do erro material pode ser tratada como saneamento de omissão indireta (já que havia um dever de ofício de correção que não foi feito), mas por ser imune à preclusão, não necessita de embargos de declaração para ser eliminado. O tema será tratado mais adiante, quando abordamos as hipóteses de oponibilidade dos embargos de declaração no Projeto de "novo" Código de Processo Civil.

${ }^{37}$ Interessante observar que as duas situações agora previstas no mesmo dispositivo (artigo 463 de 1973, o qual corresponde ao artigo 494 do CPC atual), no Código de Processo Civil de 1939 estavam topologicamente distantes, pois a correção dos erros materiais estava disposta no artigo 285 enquanto a extirpação dos vícios da omissão, contradição e obscuridade estava autorizada no artigo 862 do mesmo diploma. A anotação é importante, pois apesar da distância entre os artigos 285 e 862, havia quem os analisava de forma conjunta, partindo da mesma raiz. No sentido: Hortêncio Catunda de Medeiros (Recursos atípicos. Rio de Janeiro: Forense, 1980, p. 65-68) aponta que tanto o requerimento da correção do erro material, como os embargos de declaração não poderiam ser vistos como recursos propriamente ditos, sendo melhor falar em figuras assemelhadas aos recursos atípicos, pois ambas postulações visam aperfeiçoar a decisão e não reformá-la. Assim, apesar das diferenças, reconhece que nas duas situações há um objetivo de sanear a decisão "sem substituí-la por outra". (ob. cit. p.. 68). Também no tema, confira-se: Luiz Machado Guimarães (A revisão do código de processo civil. In Estudos de direito processual civil. Rio de Janeiro: Jurídica Universitária, 1969, p. 146).
} 
Revista Eletrônica de Direito Processual - REDP.

Rio de Janeiro. Ano 10. Volume 17. Número 2. Julho a Dezembro de 2016

Periódico Semestral da Pós-Graduação Stricto Sensu em Direito Processual da UERJ

Patrono: José Carlos Barbosa Moreira. ISSN 1982-7636. pp. 579-622

www.redp.uerj.br

Note-se, com atenção, que o pleito feito através de embargos de declaração obsta - até o seu julgamento - os efeitos preclusivos (em marcha para a formação da coisa julgada) que decorrem dos atos judiciais decisórios ${ }^{38}$. Tal característica é deveras interessante e elimina a tese de que os embargos de declaração são simples incidente processual, já que por essência estes últimos são marcados pela acessoriedade e incidentalidade. Não há nos embargos declaratórios a ocorrência de fenômeno (ou deslocamento) secundário à questão, senão a correção do ato judicial nos limites postos pelo legislador dentro do eixo da própria questão em debate. Mais ainda, os embargos declaratórios agem com força capaz de inibir (naquele momento, até o seu julgamento) os efeitos da preclusão e coisa julgada, situação que não é intima dos incidentes processuais, mas sim aos recursos como mola motriz. ${ }^{39}-40$

Por tais razões, cremos que os embargos de declaração não podem ser afastados do cardápio dos recursos, nada obstante possuírem peculiaridades que nos levam a colocálos como uma espécie própria (recurso de saneamento), cuja matriz - atualmente - é constitucional, em prestígio a um modelo democrático de processo, em razão do disposto ao longo da Constituição Federal de 1988 (especialmente o disposto nos incisos IX e X do artigo 93). ${ }^{41}$

\footnotetext{
${ }^{38}$ No tema: Pontes de Miranda (Embargos, prejulgados e revista no direito processual civil brasileiro. Rio de Janeiro: A. Coelho Branco Editor, 1937, p. 152), Antonio Carlos Costa e Silva (Dos recursos em primeiro grau de jurisdição. São Paulo: Editora Juriscredi, 1974, p. 203) e Helvécio de Gusmão (Código do processo civil e commercial para o districto federal. Rio de Janeiro: Jacynto Ribeiro dos Santos Editor, 1931, p. 151152).

${ }^{39}$ Sobre a natureza jurídica e os limites do incidente (como fenômeno processual), confira-se Marcelo Abelha Rodrigues (Suspensão de segurança. São Paulo: Revista dos Tribunais, 2000, p. 42-52).

${ }^{40}$ De todo modo, mesmo sem se atentar para a estrutura geral dos incidentes processuais, Alfredo de Araújo Lopes da Costa diz se tratar de um incidente que "suspende o prazo do recurso" (Manual elementar de direito processual. Rio de Janeiro: Forense, 1956, p. 167), afirmação esta que, na nossa opinião, só reforça a idéia da natureza recursal, diante da importância de obstar os efeitos da preclusão e coisa julgada.

${ }^{41}$ Os embargos de declaração são o meio apto para afastar a nulidade (afirmada constitucionalmente) que pode acoimar a fundamentação (motivação decisória), pois estes, ao contrário de outros recursos, permitem dicção suplementar de natureza saneadora, a fim de dar cabo aos deslizes da falta de completude, da incoerência de premissas e (ou) da falta de clareza que podem estar viciando a fundamentação ${ }^{41}$. Os embargos de declaração são, portanto, instrumento que permite a efetivação da garantia da motivação decisória (artigo 93, IX e X), no seu contorno mais amplo: decisão completa, coerente (lógica) e clara. O tema é amplamente abordado na nossa tese de doutoramento (Embargos de Declaração: Recurso de saneamento com função constitucional. FADISP, Orientação Eduardo Arruda Alvim, 2012, p. 399-409). No sentido, com pequenas variações: Teresa Arruda Alvim Wambier (Omissão Judicial e Embargos de Declaração. Revista dos Tribunais: São Paulo, 2005, p. 32-33), Joaquim Felipe Spadoni (A Função
} 
Revista Eletrônica de Direito Processual - REDP.

Rio de Janeiro. Ano 10. Volume 17. Número 2. Julho a Dezembro de 2016

Periódico Semestral da Pós-Graduação Stricto Sensu em Direito Processual da UERJ

Patrono: José Carlos Barbosa Moreira. ISSN 1982-7636. pp. 579-622

www.redp.uerj.br

\section{HIPÓTESES DE CABIMENTO}

Na redação original, os incisos I e II do artigo 275 do Código Eleitoral admitiam os embargos de declaração para sanear obscuridade, dúvida, contradição e a omissão (isto é, hipóteses de erro in procedendo, devidamente tipificadas pelo legislador $)^{42}$.

Considerando a data de edição do Código Eleitoral (1964), percebe-se o distanciamento das hipóteses de oponibilidade contidas no Código de Processo Civil vigente à época, pois, como já vimos por diversas oportunidades, o diploma de 1939 não contemplou a dúvida como situação objetiva para o cabimento dos embargos de declaração. A dúvida como causa de oponibilidade dos declaratórios pode ter sido influência do Código de Processo Penal (1941), embora esta não esteja expressa nos seus dispositivos. $^{43}$

A questão foi alvo de crítica abalizada ${ }^{44}$, valendo-se de semelhante motivação dos reclames que ocorreram quando da inclusão da dúvida na redação original do Código de

constitucional dos embargos de declaração e suas hipóteses de cabimento. In Aspectos polêmicos e atuais dos recursos cíveis e outros meios de impugnação. Volume 8. Nelson Nery e Teresa Arruda Alvim Wambier (Coords). São Paulo: Revista dos Tribunais, 2005, p. 243, José Rogério Cruz e Tucci (A motivação da sentença no processo civil. São Paulo: Saraiva, 1987, p. 20-21), Candido Rangel Dinamarco (Instituições de direito processual civil. Volume I. São Paulo: Malheiros, 2001, p. 241) e José Carlos Vieira de Andrade, a "justificabilidade objetiva" ( $O$ dever da fundamentação expressa de actos administrativos. Coimbra: Almedina, 2007, p. 232-239).

42 Explicando os motivos pelos quais as hipóteses de cabimento dos embargos de declaração devem ser vistas como erro in procedendo, confira-se: Rodrigo Mazzei (Embargos de declaração e a omissão indireta (matérias que devem ser resolvidas de ofício, independentemente de arguição prévia pelo interessado). In: Os poderes do juiz e o controle das decisões judiciais: estudos em homenagem à Professora Teresa Arruda Alvim Wambier. José Miguel Garcia Medina; Luana Pedrosa de Figueiredo Cruz; Luis Otávio Sequeira de Cerqueira; Luiz Manoel Gomes Junior. (Orgs.). São Paulo: Revista dos Tribunais, 2008, p. 58-64). No mesmo sentido: Flávio Cheim Jorge (Teoria geral dos recursos cíveis. 3a . ed. São Paulo: Revista dos Tribunais, 2007, p. 262).

${ }^{43}$ Como antes gizado, nos artigos 382 e 619 do Código de Processo Penal, há previsão de manejo dos embargos de declaração quando houver "ambigüidade" na decisão, situação que cria ambiente para a análise acerca da previsão da dúvida em tal diploma, ainda que com outra roupagem de chamada.

${ }^{44}$ No sentido: Sérgio Ferraz (Recursos aos tribunais regionais. In Direito eleitoral. Carlos Mario da Silva Velloso e Carmen Lúcia Antunes Rocha (Coords.). Belo Horizonte: Del Rey, 1996, p. 374). 
Revista Eletrônica de Direito Processual - REDP.

Rio de Janeiro. Ano 10. Volume 17. Número 2. Julho a Dezembro de 2016

Periódico Semestral da Pós-Graduação Stricto Sensu em Direito Processual da UERJ

Patrono: José Carlos Barbosa Moreira. ISSN 1982-7636. pp. 579-622

www.redp.uerj.br

Processo Civil de 1973, situação hoje superada após a reforma implementada pela Lei $8.950 / 94 .^{45}$

De forma semelhante à doutrina que trata do processo civil comum, a dúvida (para ter efeito objetivo) é tratada no processo eleitoral como manifestação das outras hipóteses de oponibilidade dos embargos de declaração, notadamente da obscuridade ${ }^{46}$.

Vale registrar, outrossim, que o Regimento Interno do Tribunal Superior Eleitoral (datado de 1952) não contempla a dúvida como hipótese de oponibilidade, nos termos do seu artigo 26, caput.

Quadra destacar que o artigo 275 do Código Eleitoral teve sua redação reformulada. Esse dispositivo, atualmente, determina que serão "admissíveis embargos de declaração nas hipóteses previstas no Código de Processo Civil”, Assim, as hipóteses de cabimento dos embargos de declaração no processo eleitoral são exatamente as tratadas no artigo 1.022 do aludido diploma processual civil.

Trata-se, portanto, de medida que buscou a unificação do sistema recursal, pois a alteração também foi empreendida no âmbito dos juizados especiais (arts. 1.065 e 1.066 do novo CPC) retirando-se a dúvida como hipótese de oponibilidade dos embargos declaratórios no ambiente da Lei 9.099/95.

\section{DAS DECISÕES EMBARGÁVEIS}

\footnotetext{
${ }^{45}$ Muitas foram as críticas em relação ao texto original do Código de Processo Civil de 1973 que tratava da dúvida como hipótese de manejo dos embargos de declaração. Confira-se (entre vários): José Carlos Barbosa Moreira (Comentários ao Código de Processo Civil. 2a . edição. Volume V. Rio de Janeiro: Editora Forense, 1976, p. 516). Wellington Moreira Pimentel (Comentários ao código de processo civil. Volume III. São Paulo: Revista dos Tribunais, 1975, p. 535-536), Luís Antônio de Andrade (Aspectos e inovações do código de processo civil: processo de conhecimento. Rio de Janeiro: Livraria Francisco Alves Editora, 1974, p. 207208), Jônatas Milhomes (Dos recursos cíveis. Rio de Janeiro: Forense, 1991, p. 293), e Alexandre de Paula (Código de processo civil anotado. Volume II. 6a . ed.. São Paulo: Revista dos Tribunais, 1994, p. 2167).

${ }^{46}$ No tema, Adriano Soares da Costa afirma que: "A dúvida, de que fala o inciso I deste artigo [artigo 275], é subsumível ao conceito de obscuridade ou contradição (elemento objetivo) que causa ao leitor do decisum um estado psicológico de dúvida. Assim, ela não se encontra no acórdão, mas no sujeito do leitor, provocada pela obscuridade ou contradição, que são atacadas pelo manejo dos embargos declaratórios" (Instituições de Direito Eleitoral. 5. ed.. Belo Horizonte, Del Rey, 2002, p. 642). Próximos: Paulo Henrique dos Santos Lucon e José Marcelo Menezes Vigliar (Código eleitoral interpretado. 2a . ed. São Paulo: Atlas, 2011, p. $345)$.
} 
Rio de Janeiro. Ano 10. Volume 17. Número 2. Julho a Dezembro de 2016

Na redação original do art. 275 do Código Eleitoral, parte da doutrina defendia que a admissibilidade dos declaratórios só se verificava em relação às decisões do juízo superior, e não quanto às de primeira instância - aquelas proferidas por juízes ou Juntas eleitorais. Esta linha se apegava à literalidade daquilo que estava disposto no artigo já citado, o qual afirmava que os embargos de declaração eram o remédio para eliminar a "obscuridade, dúvida ou contradição" que constavam no acórdão; ou, ainda, ao falar de ponto omisso sobre o qual o Tribunal devia se pronunciar. Como não havia nenhum outro dispositivo no Código Eleitoral prevendo os embargos de declaração em primeiro grau, segundo os defensores de tal linha de pensamento, o legislador fez clara restrição que deveria ser prestigiada. ${ }^{47}$

De outro lado, percebia-se uma segunda corrente que defendia o cabimento dos embargos de declaração em primeiro grau e nos Tribunais quando se tratasse de matéria cível eleitoral. Aqueles pertinentes ao processo eleitoral criminal deveriam estar limitados à alçada dos Tribunais . ${ }^{48}$

Por fim, já sobre a vigência do Código de 1973, detecta-se uma terceira via que firmava entendimento quanto à possibilidade de interposição de embargos de declaração também contra sentença de primeiro piso. Defendia-se a aplicação subsidiária do supracitado texto legal neste contexto eleitoral. Essa inclinação por parte da doutrina e da jurisprudência foi adotada pelo legislador do CPC de 2015, pois este, ao elaborar a sua Parte Geral, correspondente ao Livro I, em seu artigo 15, determinou, expressamente, a aplicação supletiva e subsidiária das normas do NCPC aos processos eleitorais, trabalhistas ou administrativos.

\footnotetext{
${ }^{47}$ No sentido: Adriano Soares da Costa (Instituições de Direito Eleitoral. 5. ed.. Belo Horizonte, Del Rey, 2002, p. 641-642) e Fávila Ribeiro (Direito Eleitoral. 5. ed. Rio de Janeiro: Forense, 2000. p. 584).

${ }^{48}$ No sentido: Joel José Cândido (Direito eleitoral brasileiro. 6. ed. rev., ampl. e atual. São Paulo: Edipro, 1996. p.224).
} 
Revista Eletrônica de Direito Processual - REDP.

Rio de Janeiro. Ano 10. Volume 17. Número 2. Julho a Dezembro de 2016

Periódico Semestral da Pós-Graduação Stricto Sensu em Direito Processual da UERJ

Patrono: José Carlos Barbosa Moreira. ISSN 1982-7636. pp. 579-622

wWW.redp.uerj.br

Esta última posição que já vinha tendo eco na jurisprudência eleitoral ${ }^{49}$, deve

ganhar ainda mais força com a recente posição legislativa mencionada. Contudo, há que se observar o prazo de 03 (três) dias, determinado pelo Código Eleitoral, para o manejo dos embargos de declaração, já que este é o prazo vulgar para os recursos que atacarão às sentenças de piso. ${ }^{50}$

Não suficiente, a nova redação do art. 275 do Código Eleitoral faz alusão tanto ao juiz $\left(\S 3^{\circ}\right)$, quanto ao tribunal $\left(\S^{\circ}\right)$, em evidente indicativo de que os embargos declaração devem ser admitidos contra qualquer decisão.

Sem prejuízo ao disposto no CPC-15, o ponto chave do cabimento dos embargos de declaração contra toda e qualquer decisão judicial proferida no âmbito do processo eleitoral se finca no disposto do artigo 93, IX, da Constituição Federal de 1988. Não há limitação na norma constitucional em relação à garantia de se obter decisão judicial motivada, não sendo lícito (até porque seria inconstitucional) admitir restrição de natureza infraconstitucional.

\footnotetext{
${ }^{49}$ No sentido, confira-se: "Mandado de segurança, decisão que inadmite a interposição de embargos de declaração em sentença de primeiro grau. Segurança concedida. Das sentenças de primeiro grau no processo eleitoral, cabe embargos de declaração. Aplicação subsidiaria do processo civil para alcançar seu cabimento em relação às sentenças de juízes e juntas eleitorais". (TRE-MT, MS n ${ }^{\circ}$ 105/92, Acórdão no 10130 de 30/07/1992, Relator Juiz JOSE SILVERIO, DJ 03/08/1992, p. 03). Próximo: TRE-RS, Recurso (registro de candidato ${ }^{\circ} 3852004$ ), acórdão de 27/08/2004, Relatora Juiza MYLENE MARIA MICHEL, publicado em sessão (01/09/2004).

${ }^{50}$ Não se justificaria, portanto, prazo maior para os embargos de declaração do que para o recurso posterior. Contra, entendendo que o prazo deve ser o do Código de Processo Civil, Décio Luiz José Rodrigues afirma que: "Como não há previsão da interposição de embargos declaratórios de sentença, entendemos que, por analogia, devem se aplicadas as normas do Código de Processo Civil a respeito, conforme os arts. $535 \mathrm{e}$ seguintes do CPC de 1973. Assim, no caso de obscuridade, contradição ou omissão de sentença em matéria eleitoral (O Código de Processo Civil exclui a palavra "dúvida"), cabível é a interposição dos embargos declaratórios em cinco dias da publicação da sentença, com a interrupção (e não a mera suspensão) do prazo para outros recursos, e se forem protelatórios, ainda será possível a aplicação de multa ao recorrente" (Direito eleitoral: ações:recursos e propaganda. São Paulo: Rideel, 2006, p. 101). Não concordamos com a doutrina transcrita, na medida em que cria dois sistemas distintos para o aviamento da mesma figura jurídica, em descompasso com a segurança jurídica e retroagindo a um grande defeito da redação original do Código de Processo Civil de 1973, que possuía duplo (e diferente) regramento em relação aos embargos de declaração ofertados contra as sentenças e os acórdãos. Abominando a idéia de duplo tratamento dos embargos de declaração, confira-se (entre muitos): Pontes de Miranda (Comentários ao código de processo civil. Tomo V. Rio de Janeiro: Forense, 1974, p. 104).
} 
Revista Eletrônica de Direito Processual - REDP.

Rio de Janeiro. Ano 10. Volume 17. Número 2. Julho a Dezembro de 2016

Periódico Semestral da Pós-Graduação Stricto Sensu em Direito Processual da UERJ

Patrono: José Carlos Barbosa Moreira. ISSN 1982-7636. pp. 579-622

wWW.redp.uerj.br

O conceito de decisão motivada do artigo 93, IX, é amplo e acaba por alcançar

todas as hipóteses de oponibilidade dos embargos de declaração. Assim, toda e qualquer decisão deve ser completa (=sem omissão), lógica (=sem contradição) e clara (= sem obscuridade). ${ }^{51}$ Não se pode conceber, nos dias atuais, a interpretação restritiva do artigo 275 do Código Eleitoral, pois esta postura navegará contra o comando da bússola constitucional. ${ }^{52}$

Dessa forma, a questão não deveria se resolver apenas pela aplicação subsidiária de diplomas infraconstitucionais, mas, sim, a partir da premissa e iluminação de garantia e diretriz de cunho constitucional (artigo 93, IX), de modo que toda e qualquer dicção judicial (ou até administrativa - artigo 93, X) possa ser desafiada por embargos de declaração se não estiver com a sua motivação perfeita (isto é, completa, clara e precisa).

Não é à toa, portanto, que vige em relação aos embargos de declaração o princípio da ampla embargabilidade ${ }^{53}$, que permite o aviamento dos declaratórios contra qualquer

51 De forma mais detalhada, confira-se: Rodrigo Reis Mazzei (Embargos de Declaração: Recurso de saneamento com função constitucional. FADISP, Orientação Eduardo Arruda Alvim, 2012, p. 399-409). Com idéia próxima, confira-se: Jose Rogério Cruz e Tucci (A motivação da sentença no processo civil. São Paulo: Saraiva, 1987, p. 20), Teresa Arruda Alvim Wambier (Omissão Judicial e Embargos de Declaração. Revista dos Tribunais: São Paulo, 2005, p. 32-33) e Joaquim Felipe Spadoni (A Função constitucional dos embargos de declaração e suas hipóteses de cabimento. In: Aspectos polêmicos e atuais dos recursos cíveis e outros meios de impugnação. Volume 8. Nelson Nery e Teresa Arruda Alvim Wambier (Coords). São Paulo: Revista dos Tribunais, 2005, p. 243).

${ }^{52}$ Há precedentes jurisprudenciais com linha próxima a que defendemos, confira-se: “(...) A jurisprudência é remansosa no sentido do cabimento de embargos de declaração contra qualquer decisão judicial, não podendo o artigo 275 do Código Eleitoral ser interpretado restritivamente, sob pena de violar princípios constitucionais, como o da ampla defesa e do contraditório" (TRE-RJ, MS nº 665, Acórdão no 38.240 de 03/12/2009, Relator Juiz LUIZ UMPIERRE DE MELLO SERRA, DJ, Tomo 226, Data 11/12/2009, p. 01). Igualmente: TRE-RJ, Recurso Eleitoral $n^{\circ}$ 7250, Acórdão $n^{\circ} 38.242$ de 03/12/2009, Relator Juiz LUIZ UMPIERRE DE MELLO SERRA, DJ, Tomo 226, Data 11/12/2009, p. 01.

53 De construção doutrinária [Vicente Miranda (Embargos de Declaração no Processo Civil Brasileiro. Saraiva: São Paulo, 1990, p. 45] e aceito pela jurisprudência, o princípio da ampla embargabilidade está prestigiado (até agora) no Projeto do "novo" Código de Processo Civil (Lei do Senado 166/2010). A diretriz estava presente na redação original no artigo 937 e continua (após pequenas mudanças e do deslocamento para o artigo 976) no texto consolidado após alterações no relatório-geral do Senador Valter Pereira. O caput do artigo 976 é eloqüente: “cabem embargos de declaração contra qualquer decisão monocrática e colegiada". No tema, com doutrina mais atual, confira-se (entre vários): Daniel Ustárroz e Sergio Gilberto Porto (Manual dos recursos cíveis. 3a . ed. Porto Alegre: Livraria do Advogado, 2011, p. 198-199) e Bernardo Pimentel Souza (Introdução aos Recursos Cíveis e à Ação Rescisória. 7. ed. São Paulo: Saraiva, 2010, p. 419-422). 
Revista Eletrônica de Direito Processual - REDP.

Rio de Janeiro. Ano 10. Volume 17. Número 2. Julho a Dezembro de 2016

Periódico Semestral da Pós-Graduação Stricto Sensu em Direito Processual da UERJ

Patrono: José Carlos Barbosa Moreira. ISSN 1982-7636. pp. 579-622

www.redp.uerj.br

ato decisório ${ }^{54}$ (e até, em certos casos, contra despachos ${ }^{55}$ ), bastando, para tanto, a abstrata

existência dos deslizes judicantes que a figura se propõe a corrigir: omissão, contradição e

obscuridade..$^{56}$

Não nos parece possível se criar uma diferenciação no processo eleitoral, devendo

também no seu âmbito se aplicar o princípio da ampla embargabilidade, diante da matriz constitucional e da própria função dos embargos de declaração.

\footnotetext{
${ }^{54}$ No sentido (entre muitos): Ivan de Hugo Silva (Recursos no novo Código de processo civil. Rio de Janeiro: Forense, 1976, 284), Nelson Nery Júnior (Atualidades sobre o processo civil. 2a. ed.. São Paulo: Revista dos Tribunais, 1996, p. 175), Sergio Bermudes (Comentários ao Código de Processo Civil. Vol.VII. São Paulo: Revista dos Tribunais, 1975, p. 211) e Pontes de Miranda (Comentários ao código de processo civil. Tomo VII. Rio de Janeiro: Forense, 1975, p. 400-401). Contra, não admitindo os embargos de declaração contra as decisões interlocutórias: Antônio Macedo de Campos (Recursos no processo civil. São Paulo: Sugestões Literárias, 1980, p. 269 e 272) e Wellington Moreira Pimentel (Comentários ao código de processo civil. Volume III. São Paulo: Revista dos Tribunais, 1975, p. 530-531).

$55 \mathrm{Na}$ verdade, ao se compreender a matriz constitucional e, especialmente, a natureza dos vícios que os embargos de declaração devem sanar, haverá superfície para que o intérprete aceite, inclusive, o seu aviamento contra os despachos, já que estes podem causar embaraços na marcha processual quando acoimados de omissão, contradição e/ou obscuridade. Também admitindo embargos de declaração contra despachos: Araken de Assis (Manual dos Recursos. 2. ed. rev. e ampl. São Paulo: Revista dos Tribunais, 2008, p. 598), em ótimo exemplo [adotado também por Eduardo Arruda Alvim (Direito processual civil. 2a . São Paulo: Revista dos Tribunais, p. 832)], indica o despacho que designa a audiência de instrução para determinado dia, mas que deixa de constar o horário em que o ato será realizado. Há, pois, omissão que pode ser reparada por embargos declaratórios, eis que embora o conteúdo decisório seja mínimo, senão inexistente, o despacho criou situação de insegurança pelo vício da sua dicção (omissão). Na jurisprudência, confira-se: STJ, EDcl no REsp 207435/RS, Rel. Ministro GARCIA VIEIRA, PRIMEIRA TURMA, j. 03/08/1999, DJ 20/09/1999, p. 39).

${ }^{56}$ O Superior Tribunal de Justiça possui julgados variados no sentido, podendo se citar, em exemplos: "São cabíveis embargos de declaração contra qualquer decisão judicial." (RCDESP no Ag. 1223987/PR, Rel. Ministro JOÃO OTÁVIO DE NORONHA, QUARTA TURMA, j. 24/08/2010, DJe 03/09/2010); “(...) Até pouco tempo atrás, era discordante a jurisprudência no sentido do cabimento dos embargos de declaração, com predominância de que os aclaratórios só eram cabíveis contra decisões terminativas e proferidas (sentença ou acórdãos), não sendo possível a sua interposição contra decisões interlocutórias e, no âmbito dos Tribunais, em face de decisórios monocráticos. 3. No entanto, após a reforma do CPC, por meio da Lei ${ }^{\circ}$ 9.756, de 17/12/1998, D.O.U. de 18/12/1998, esta Casa Julgadora tem admitido o oferecimento de embargos de declaração contra quaisquer decisões, ponham elas fim ou não ao processo. 4. Nessa esteira, a egrégia Corte Especial do Superior Tribunal de Justiça firmou entendimento de ser cabivel a oposição de embargos declaratórios contra quaisquer decisões judiciais, inclusive monocráticas e, uma vez interpostos, interrompem o prazo recursal, não se devendo interpretar de modo literal o art. 535, CPC, vez que atritaria com a sistemática que deriva do próprio ordenamento processual. (EREsp n ${ }^{\circ}$ 159317/DF, Rel. Min. Sálvio de Figueiredo Teixeira, DJ de 26/04/1999) 5. Precedentes de todas as Turmas desta Corte Superior. (...)" (REsp 478.459/RS, Rel. Ministro JOSÉ DELGADO, PRIMEIRA TURMA, j. 25/02/2003, DJ 31/03/2003, p. 175). Confira-se, ainda, em sentido semelhante: AgRg no REsp 1154775/RJ, Rel. Ministro OG FERNANDES, SEXTA TURMA, j. 03/03/2011, DJe 21/03/2011; REsp 1.147.525/DF, Rel. Min. MAURO CAMPBELL MARQUES, SEGUNDA TURMA, j. 17/8/2010, DJe 20/9/2010; AgRg no REsp 1103431/RJ, Rel. Ministra DENISE ARRUDA, PRIMEIRA TURMA, j. 05/11/2009, DJe 26/11/2009; REsp 788.597/MG, Rel. Ministro JOSÉ DELGADO, PRIMEIRA TURMA, j. 18/04/2006, DJ 22/05/2006, p. 168; REsp 762.384/SP, Rel. Ministro TEORI ALBINO ZAVASCKI, PRIMEIRA TURMA, j. 06/12/2005, DJ 19/12/2005, p. 262.
} 
Revista Eletrônica de Direito Processual - REDP.

Rio de Janeiro. Ano 10. Volume 17. Número 2. Julho a Dezembro de 2016

Periódico Semestral da Pós-Graduação Stricto Sensu em Direito Processual da UERJ

Patrono: José Carlos Barbosa Moreira. ISSN 1982-7636. pp. 579-622

www.redp.uerj.br

\section{EMBARGOS DE DECLARAÇÃO E O PRINCÍPIO DA FUNGIBILIDADE}

Ao longo dos anos firmou-se posição no Tribunal Superior Eleitoral de que os embargos de declaração apresentados contra decisões unipessoais dos relatores no âmbito dos Tribunais devem ser recepcionados como $\operatorname{agravo}^{57}$, criando a situação da fungibilidade compulsória, seguindo trilha de posição de outras Cortes Superiores. ${ }^{58}{ }_{-}^{59}{ }_{-} 60$

Com todo respeito, o posicionamento praticamente excluí os embargos de declaração do âmbito das decisões monocráticas proferidas pelo relator, pois, em verdade, não se julgará os declaratórios, mas sim outro recurso (agravo), já que estará ocorrendo

\footnotetext{
${ }^{57}$ No sentido: "Na linha da jurisprudência do Tribunal, recebem-se como agravo regimental os embargos de declaração opostos contra decisão individual" (TSE, Embargos de Declaração em Recurso Especial Eleitoral $\mathrm{n}^{\circ}$ 58245, Acórdão de 02/03/2011, Relator Ministro ARNALDO VERSIANI LEITE SOARES, DJE, 12/05/2011, p. 31).

${ }^{58}$ Confira-se: "Admite-se o recebimento de embargos declaratórios opostos à decisão monocrática do relator como agravo interno, em atenção aos princípios da economia processual e da fungibilidade recursal." (STJ, EDcl nos EREsp 1136867/SC, Rel. Ministro HUMBERTO MARTINS, PRIMEIRA SEÇÃO, julgado em 23/02/2011, DJe 10/03/2011). No mesmo sentido (entre vários): EDCL no AgRg no Ag 1.252.150/BA, Rel. Ministro BENEDITO GONÇALVES, Primeira Turma, DJe 26/08/2011; EDcl no CC 104.719/RJ, Rel. Ministro JOÃO OTÁVIO DE NORONHA, Segunda Seção, DJe, 20/10/2010; EDcl nos EREsp 1.168.312/PE, Rel. Ministro BENEDITO GONÇALVES, Primeira Seção, DJe 29/09/2010; EDcl no Resp 1.196.576/SE, Rel. Ministro ARNALDO ESTEVER, Primeira Turma, DJe 20/10/2010. "Embargos de declaração conhecidos como agravo regimental, em atenção ao princípio da fungibilidade recursal" (STF RE 350261 ED/MS, Primeira Turma, Rel. Min. Sepúlvida Pertence). No mesmo sentido (entre vários): Pet 4.837-ED, Rel. Ministra CARMEN LÚCIA, Tribunal Pleno, j. 07/04/2011; RE 546.525-ED, Rel. Ministra ELLEN GRACIE, $2^{\text {a }}$ Turma, j. 05/04/2011; AI 783653-ED, Rel. Ministro LUIZ FUX, $1^{\text {a }}$ Turma, j. 07/06/2011; AI 547.827-ED, Rel. Ministro DIAS TOFFOLI, $1^{\text {a }}$ Turma, j. 09/03/2011.

${ }^{59} \mathrm{Na}$ justiça do Trabalho a matéria está tratada na Súmula 421 do Tribunal Superior do Trabalho: "I - Tendo a decisão monocrática de provimento ou denegação de recurso, prevista no art. 557 do CPC de 1973 (artigo 932, III do atual CPC), conteúdo decisório definitivo e conclusivo da lide, comporta ser esclarecida pela via dos embargos de declaração, em decisão aclaratória, também monocrática, quando se pretende tão-somente suprir omissão e não modificação do julgado. II - Postulando o embargante efeito modificativo, os embargos declaratórios deverão ser submetidos ao pronunciamento do Colegiado, convertidos em agravo, em face dos princípios da fungibilidade e celeridade processual.

${ }^{60}$ Há, de toda forma, alguns julgamentos isolados nos Tribunais regionais que não se valem da fungibilidade compulsória. Confira-se: "Embargos declaratórios. Decisão monocrática. Na hipótese do inciso II do art. 535 do Código de Processo Civil é cabível embargos de declaração contra decisão monocrática de Relator" (TRE-MG, EXCEÇÕES nº 6142001, Acórdão ${ }^{\circ} 735$ de 27/08/2001, Relator Juiz ORLANDO ADÃO CARVALHO, DJMG 19/10/2001, p. 78). Igualmente: TRE-RS, INVESTIGAÇAO JUDICIAL ELEITORAL no 752004, Acórdão de 17/12/2004, Relator Juiz ALMIR PORTO DA ROCHA FILHO, DJE Tomo 021, Data 04/02/2005, p. 103-104.
} 
Revista Eletrônica de Direito Processual - REDP.

Rio de Janeiro. Ano 10. Volume 17. Número 2. Julho a Dezembro de 2016

Periódico Semestral da Pós-Graduação Stricto Sensu em Direito Processual da UERJ

Patrono: José Carlos Barbosa Moreira. ISSN 1982-7636. pp. 579-622

www.redp.uerj.br

uma conversão obrigatória sob a égide da fungibilidade. Este entendimento é, na nossa

visão, equivocado, pois equipara os embargos de declaração ao agravo, recurso que possui estrutura e objetivos distintos ${ }^{61}$.

Basta pensar que o espectro dos embargos de declaração é limitado à alegação de omissão, contradição e obscuridade, ou seja, hipóteses de erro in procedendo já tipificadas pelo legislador, não podendo o embargante fugir deste gabarito. $\mathrm{O}$ agravo antes atrelado ao artigo $557^{62}$ do Código de Processo Civil de 1973 - em exemplo mais marcante - não se vinculava a tais matérias e seu foco maior era o error in judicando, ou seja, questões sobre o próprio conteúdo do julgamento. Neste passo, a cobertura das matérias dos embargos declaratórios era, por regra, diferente e menor do que a atacável via agravo.

A fungibilidade entre instrumentos que não são iguais ${ }^{63}$ pode ser perniciosa e prejudicial ao recorrente, somente sendo possível cogitar ocorrer se for dado ao embargante (recorrente) a possibilidade de emendar os embargos de declaração, ou melhor, transformá-los em agravo, para o fim de expandir as matérias, a fim de evitar a preclusão. Assim, a fungibilidade obrigatória acaba por afastar os embargos de declaração das decisões unipessoais, pois, se estes serão julgados como agravo, significa dizer que os embargos foram tidos como incabíveis e a fungibilidade é decorrente de sua inadequação. ${ }^{64}$

${ }^{61}$ Correta a assertiva de Francisco Ferreira Jorge Neto e Jouberto de Quadros Pessoa Cavalcante: "O efeito modificativo não desconfigura os embargos e a sua natureza jurídica (...) seu intuito não é o reexame da decisão, porém, a adaptação de falhas da sentença à realidade dos autos" (Recursos no processo do trabalho. Rio de Janeiro: Lúmen Júris, 2007, p. 272).

62 Corresponde ao artigo 932 do Novo Código de Processo Civil, o qual, também, disciplina os "deverespoderes" a serem exercitados no âmbito dos tribunais pelo relator. A previsão normativa possui uma completude maior e um refinamento técnico quando comparada ao artigo 557 do CPC de 1973.

63 No tema Bolívar Viégas Peixoto afirmou que: "Posicionamo-nos contrariamente à Súmula n. 421 do Tribunal Superior do Trabalho, no sentido de que, se os embargos tiverem efeito modificativo, deverão ser convertidos, em face do princípio da fungibilidade e da celeridade processual, no recurso de agravo mencionado no $\S 1^{\circ}$ [artigo 557], porque não vemos identidade entre eles, tendo cada um os seus pressupostos, que são de tal monta distintos que não se aproveitam. Não há unicidade nestes pressupostos a ensejar o princípio da fungibilidade" (Embargos de declaração em face de decisões proferidas com base no art. 557 do CPC. In Embargos de declaração no processo do trabalho. Vitor Salino de Moura Eça (Coord.). São Paulo: LTr, 2010, p. 130).

${ }^{64}$ Diante do nefasto quadro, a doutrina sugere - como solução segura - que os embargos de declaração contra decisões unipessoais sejam descartados, devendo a parte interpor diretamente o "agravo na sua forma regimental". Confira-se: Francisco Ferreira Jorge Neto e Jouberto de Quadros Pessoa Cavalcante (Recursos no processo do trabalho. Rio de Janeiro: Lúmen Júris, 2007, p. 273). 
Revista Eletrônica de Direito Processual - REDP.

Rio de Janeiro. Ano 10. Volume 17. Número 2. Julho a Dezembro de 2016

Periódico Semestral da Pós-Graduação Stricto Sensu em Direito Processual da UERJ

Patrono: José Carlos Barbosa Moreira. ISSN 1982-7636. pp. 579-622

www.redp.uerj.br

A antiga posição majoritária no Tribunal Superior Eleitoral, ou seja, antes da

vigência do CPC-15, criava a noção de que somente serão admissíveis embargos de declaração contra decisões unipessoais se não houver pedido de efeito modificativo, pois, caso tal ocorra, os embargos declaratórios são inadequados [via de conseqüência, serão transformados (isto é, admitidos) no formato de agravo]. Pouco importa se o vício apontado nos embargos de declaração seja a omissão, a contradição ou a obscuridade: há pedido de efeito modificativo, deveria ser determinada a conversão automática.

Tal posição era insustentável, pois o mínimo que se podia esperar numa situação de fungibilidade semelhante era a intimação do recorrente para adequação da peça recursal. Não resta dúvida que violentava de forma carnal o princípio da fungibilidade a permuta de figura processual com prejuízo para o recorrente ${ }^{65}$, situação ocorrente na conversão dos embargos de declaração para o agravo, diante do limitado material que o primeiro carrega para a correção da decisão singular recorrida.

A partir da vigência do novo CPC (e sua diretriz colaborativa), não será mais possível a conversão "surpresa" dos embargos de declaração em agravo, pois o legislador inseriu regra específica que demanda a prévia intimação do postulante para ajustar a peça recursal. Com efeito, nos termos do disposto no $\S 3^{\circ}$ do art. 1.024: “O órgão julgador conhecerá dos embargos de declaração como agravo interno se entender ser este o recurso cabível, desde que determine previamente a intimação do recorrente para, no prazo de 5 (cinco) dias, complementar as razões recursais, de modo a ajustá-las às exigências do art. $1.021, \S 1^{\mathrm{o}}$.

Destarte, trata-se de postura coerente adotada na nova codificação, já que suas regras de sanabilidade, em especial o disposto no parágrafo único do art.932, abominam o

\footnotetext{
65 Não se pode cogitar em uso do princípio da fungibilidade com prejuízo da parte que teve a sua peça processual convertida, pois um dos pontos chaves da diretriz é a inexistência de prejuízo. Confira-se: No sentido, confira-se: Fernando da Fonseca Gajardoni (Flexibilização Procedimental. São Paulo: Atlas, 2008, p. 190), Guilherme Freire de Barros Teixeira (Teoria do Princípio da Fungibilidade. São Paulo: Revista dos Tribunais, 2008, p. 295) e Luiz Gustavo Tardin (Fungibilidade das Tutelas de Urgência. São Paulo: Revista dos Tribunais, 2006, p. 147-148).
} 
Revista Eletrônica de Direito Processual - REDP.

Rio de Janeiro. Ano 10. Volume 17. Número 2. Julho a Dezembro de 2016

Periódico Semestral da Pós-Graduação Stricto Sensu em Direito Processual da UERJ

Patrono: José Carlos Barbosa Moreira. ISSN 1982-7636. pp. 579-622

www.redp.uerj.br

elemento surpresa nos pronunciamentos judiciais. Isso fica ainda mais nítido quando nos deparamos com os artigos 9 e 10 desse mesmo texto legal.

\section{DA PRESERVAÇÃO DO PRAZO PARA OUTROS RECURSOS}

Segundo a redação original do art. 275 do Código Eleitoral, os embargos de declaração 'suspendiam' o prazo para interposição de outros recursos. No entanto, trazendo raízes do Código de Processo Civil de 1939, esse traçava que a suspensão não iria ocorrer se os embargos de declaração fossem tidos como manifestamente protelatórios.

Embora a letra da lei fizesse menção à suspensão do prazo, o Tribunal Superior Eleitoral entendeu que deve-se aplicar o efeito interruptivo aos embargos de declaração ${ }^{66}$. Ou seja, o manejo dos embargos declaratórios interrompe o prazo para os demais recursos, voltando-se tal contagem, assim, ao termo inicial, como se prazo algum tivesse sido consumido. ${ }^{67}$

A análise açodada da questão poderia levar ao entendimento de que a posição jurisprudencial foi firmada a partir da idéia de que o artigo 538 da legislação processual civil de 1973 tomou o espaço do dispositivo da codificação eleitoral. Contudo, tal linha de pensamento não prospera, já que se trata de postura firmada antes mesmo da edição da Lei 8.850/94 que, ao reformar o dispositivo em questão, definiu o efeito interruptivo nos embargos declaratórios previstos no processo civil comum.

Com efeito, a antiga regra do $\S 4^{\circ}$ do artigo 275 do Código Eleitoral criava grande enleio, pois o prazo dos embargos de declaração (previsto no $\S 1^{\circ}$ do mesmo dispositivo três dias) é igual para os demais recursos (artigo 258). Logo, a suspensão do prazo para os demais recursos não se operaria se o embargante consumisse todo o prazo que tinha para o

\footnotetext{
${ }^{66}$ No sentido: "AGRAVO REGIMENTAL. AGRAVO DE INSTRUMENTO. ELEIÇÕES 2008. PREFEITO. EMBARGOS DE DECLARAÇÃO. PRAZO. INTERRUPÇÃO. PROVIMENTO. 1. Os embargos de declaração interrompem o prazo para a interposição de outros recursos. Precedentes"(TSE, AgR-AI 369422; RJ; Rel. Min. Marco Aurélio Mendes de Farias Mello; DJE 05/04/2011; p. 46).

${ }^{67}$ No sentido: Paulo Henrique dos Santos Lucon e José Marcelo Menezes Vigliar (Código eleitoral interpretado. 2a . ed. São Paulo: Atlas, 2011, p. 344).
} 
Revista Eletrônica de Direito Processual - REDP.

Rio de Janeiro. Ano 10. Volume 17. Número 2. Julho a Dezembro de 2016

Periódico Semestral da Pós-Graduação Stricto Sensu em Direito Processual da UERJ

Patrono: José Carlos Barbosa Moreira. ISSN 1982-7636. pp. 579-622

www.redp.uerj.br

manejo dos embargos de declaração. Assim, de forma involuntária, o $§ 4^{\circ}$ do artigo 275 do

Código Eleitoral - se não interpretado - esgotava nocivamente os prazos dos recursos.

Fica expresso no $\S 5^{\circ}$ do art. 275 do CE, alterado pelo artigo 1.067 do NCPC, que os embargos de declaração interrompem o prazo para a interposição de recurso. Note-se que a alteração teve o objetivo de unificação do sistema recursal, pois essa modificação também se aplicou no âmbito dos juizados especiais, consoante se percebe dos arts. $1.065 \mathrm{e}$ 1.066 do mesmo diploma processual civil.

\section{EFEITO SUSPENSIVO (PROPRIAMENTE DITO)}

Outro ponto que nos chama atenção na Justiça Eleitoral é quanto à produção de efeitos para execução do decisum. É que os recursos eleitorais, nos termos do artigo 257 do Código Eleitoral ${ }^{68}$, não possuem efeito suspensivo - previsão legal que possibilita a imediata execução de qualquer decisão. Portanto, a sentença começa a produzir efeitos instantaneamente após sua prolação, exceto nos casos em que a lei exige manifestação da instância superior para a execução do julgado, podendo se tirar como exemplo o artigo 216 do Código Eleitoral ${ }^{69}{ }_{-}^{70}$.

Diante da uniformidade recursal, o disposto no artigo 257 do Código Eleitoral aparenta ser aplicável aos embargos de declaração, entretanto, tal conclusão não repudia a possibilidade de concedê-los efeito suspensivo. $\mathrm{O} \S 1^{\circ}, 1.026$ do CPC-15 traz expressamente algumas hipóteses excepcionais, em que o embargante poderá postular a concessão desse efeito, o qual subsistirá até o julgamento do recurso de saneamento, aos embargos declaratório. ${ }^{71}$-72

\footnotetext{
${ }^{68}$ Artigo 257. Os recursos eleitorais não terão efeito suspensivo.

${ }^{69}$ Artigo 216. Enquanto o Tribunal Superior não decidir o recurso interposto contra a expedição do diploma, poderá o diplomado exercer o mandato em toda a sua plenitude.

${ }^{70}$ Confira-se: Christopher Rezende Guerra Aguiar (Recursos na Justiça Eleitoral. In Atualidades do Processo Civil. Arruda Alvim e Eduardo Arruda Alvim (Coords.). Vol. I. Curitiba: Juruá Editora, 2006. p. 306).

${ }^{71}$ Admitindo a idéia de concessão de efeito suspensivo nos embargos de declaração com espeque no artigo 558 do Código de Processo Civil de 1973: Luis Guilherme Aidar Bondioli (Embargos de Declaração. São Paulo: Saraiva. 2005, p. 197-201) e Teresa Arruda Alvim Wambier (Omissão Judicial e Embargos de Declaração. Revista dos Tribunais: São Paulo, 2005, p. 92-94).
} 
Rio de Janeiro. Ano 10. Volume 17. Número 2. Julho a Dezembro de 2016

Periódico Semestral da Pós-Graduação Stricto Sensu em Direito Processual da UERJ

Patrono: José Carlos Barbosa Moreira. ISSN 1982-7636. pp. 579-622 www.redp.uerj.br

Em suma, com a nova codificação aplicada ao processo eleitoral (art. 15), a eficácia da decisão monocrática ou colegiada poderá ser suspensa pelo respectivo juiz ou relator se demonstrada a probabilidade de provimento do recurso ou, sendo relevante a fundamentação, se houver risco de dano grave ou de difícil reparação $\left(\S 1^{\circ}, 1.026\right)$.

\section{OS EMBARGOS DE DECLARAÇÃO NO "NOVO" CÓDIGO DE PROCESSO CIVIL}

O novo Código traz inovações na regulamentação dos embargos declaratórios. É imperiosa a análise dos trabalhos legislativos e a redação final que deu origem a esse novo texto legal, eis que na forma que seu artigo 15 determina que esse deverá ser utilizado de forma supletiva e subsidiaria em ambientes de leis especiais, com menção expressa ao processo eleitoral. Nesse contexto, faz-se interessante e bastante didático o paralelo entre os dispositivos pertinentes na redação CPC de 1973, e a redação atual do CPC de 2015. Confira-se:

\begin{tabular}{|c|c|}
\hline Redação atual do CPC de 1973 & Redação do Novo CPC \\
\hline $\begin{array}{l}\text { Art. 463. Publicada a sentença, o juiz só } \\
\text { poderá alterá-la: } \\
\text { I - para Ihe corrigir, de ofício ou a } \\
\text { requerimento da parte, inexatidões } \\
\text { materiais, ou Ihe retificar erros de cálculo; } \\
\text { II - por meio de embargos de declaração. }\end{array}$ & $\begin{array}{l}\text { Art. } 494^{73} \text {. Publicada a sentença, o juiz só } \\
\text { poderá alterá-la: } \\
\text { I - para corrigir-lhe, de ofício ou a } \\
\text { requerimento da parte, inexatidões } \\
\text { materiais ou erros de cálculo; } \\
\text { II - por meio de embargos de declaração. }\end{array}$ \\
\hline
\end{tabular}

72 Tratamos do tema com vagar no seguinte texto: Dos embargos de declaração. In: Dos recursos - Temas obrigatórios e atuais. (vetores recursais). Rodrigo Reis Mazzei (Coord.). Vitória: Instituto Capixaba de Estudos - ICE, 2002, v. 2, p. 381-385.

${ }^{73}$ Correspondência no Anteprojeto: art.476 
Revista Eletrônica de Direito Processual - REDP.

Rio de Janeiro. Ano 10. Volume 17. Número 2. Julho a Dezembro de 2016

Periódico Semestral da Pós-Graduação Stricto Sensu em Direito Processual da UERJ

Patrono: José Carlos Barbosa Moreira. ISSN 1982-7636. pp. 579-622

wWw.redp.uerj.br

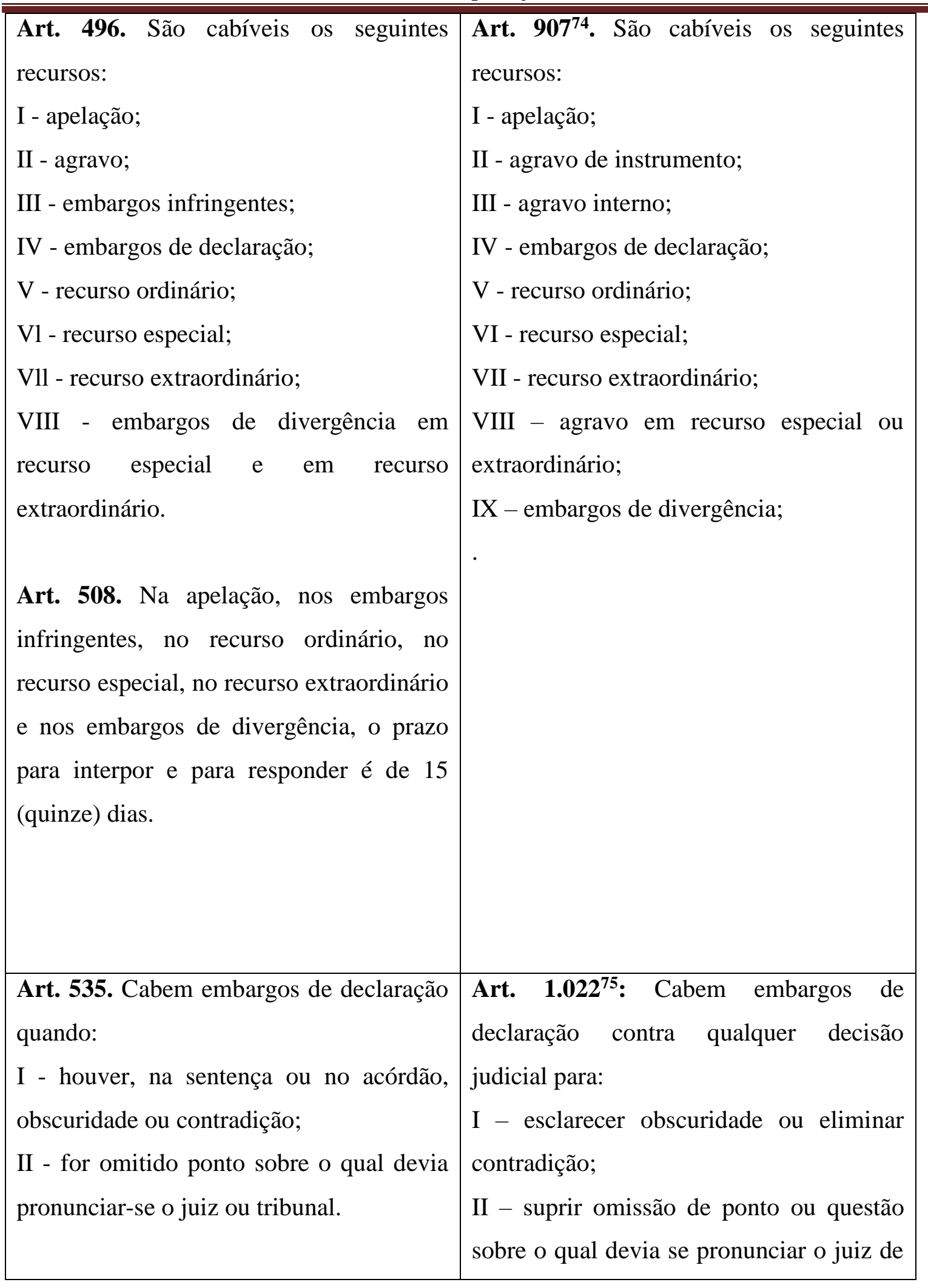

${ }^{74}$ Correspondência no Anteprojeto: art.831

${ }^{75}$ Correspondência no Anteprojeto: art.937 
Rio de Janeiro. Ano 10. Volume 17. Número 2. Julho a Dezembro de 2016

Periódico Semestral da Pós-Graduação Stricto Sensu em Direito Processual da UERJ Patrono: José Carlos Barbosa Moreira. ISSN 1982-7636. pp. 579-622 www.redp.uerj.br

\begin{tabular}{|c|c|}
\hline & $\begin{array}{l}\text { oficio ou a requerimento; } \\
\text { III - corrigir erro material. } \\
\text { Parágrafo único. Considera-se omissa a } \\
\text { decisão que: } \\
\text { I - deixe de se manifestar sobre tese } \\
\text { firmada em julgamento de casos } \\
\text { repetitivos ou em incidente de assunção } \\
\text { de competência aplicável ao caso sob } \\
\text { julgamento; } \\
\text { II - incorra em qualquer das condutas } \\
\text { descritas no art. } 489, \S 1\end{array}$ \\
\hline $\begin{array}{l}\text { Art. 536. Os embargos serão opostos, no } \\
\text { prazo de } 5 \text { (cinco) dias, em petição } \\
\text { dirigida ao juiz ou relator, com indicação } \\
\text { do ponto obscuro, contraditório ou } \\
\text { omisso, não estando sujeitos a preparo. }\end{array}$ & $\begin{array}{l}\text { Art. } \mathbf{1 . 0 2 3}^{76} \text {. Os embargos serão opostos, } \\
\text { no prazo de } 5 \text { (cinco) dias, em petição } \\
\text { dirigida ao juiz ou relator, com indicação } \\
\text { do ponto obscuro, contraditório ou } \\
\text { omisso, não estando sujeitos a preparo. }\end{array}$ \\
\hline $\begin{array}{l}\text { Art. 537. O juiz julgará os embargos em } \\
5 \text { (cinco) dias; nos tribunais, o relator } \\
\text { apresentará os embargos em mesa na } \\
\text { sessão subseqüente, proferindo voto. }\end{array}$ & $\begin{array}{l}\text { Art. 1.02477: O juiz julgará os embargos } \\
\text { em } 5 \text { (cinco) dias. } \\
\S 1^{\circ} \text { Nos tribunais, o relator apresentará os } \\
\text { embargos em mesa na sessão subsequente, } \\
\text { proferindo voto, e, não havendo } \\
\text { julgamento nessa sessão, será o recurso } \\
\text { incluído em pauta automaticamente. } \\
\S 2^{\circ} \text { Quando os embargos de declaração } \\
\text { forem opostos contra decisão de relator ou } \\
\text { outra decisão unipessoal proferida em } \\
\text { tribunal, o órgão prolator da decisão } \\
\text { embargada decidilos-á monocraticamente. }\end{array}$ \\
\hline
\end{tabular}

${ }^{76}$ Correspondência no Anteprojeto: art.938
${ }^{77}$ Correspondência no Anteprojeto: art.939 
Revista Eletrônica de Direito Processual - REDP.

Rio de Janeiro. Ano 10. Volume 17. Número 2. Julho a Dezembro de 2016

Periódico Semestral da Pós-Graduação Stricto Sensu em Direito Processual da UERJ

Patrono: José Carlos Barbosa Moreira. ISSN 1982-7636. pp. 579-622

www.redp.uerj.br

\begin{tabular}{|c|c|}
\hline & $\begin{array}{l}\S 3^{\circ} \text { O órgão julgador conhecerá dos } \\
\text { embargos de declaração como agravo } \\
\text { interno se entender ser este o recurso } \\
\text { cabível, desde que determine previamente } \\
\text { a intimação do recorrente para, no prazo } \\
\text { de } 5 \text { (cinco) dias, complementar as razões } \\
\text { recursais, de modo a ajustá-las às } \\
\text { exigências do art. 1.021, } \S 1^{\circ} \text {. } \\
\S 4^{\circ} \text { Caso o acolhimento dos embargos de } \\
\text { declaração implique modificação da } \\
\text { decisão embargada, o embargado que já } \\
\text { tiver interposto outro recurso contra a } \\
\text { decisão originária tem o direito de } \\
\text { complementar ou alterar suas razões, nos } \\
\text { exatos limites da modificação, no prazo de } \\
15 \text { (quinze) dias, contado da intimação da } \\
\text { decisão dos embargos de declaração. } \\
\S 5^{\circ} \text { Se os embargos de declaração forem } \\
\text { rejeitados ou não alterarem a conclusão do } \\
\text { julgamento anterior, o recurso interposto } \\
\text { pela outra parte antes da publicação do } \\
\text { julgamento dos embargos de declaração } \\
\text { será processado } \\
\text { independentemente de ratificação }\end{array}$ \\
\hline Sem correspondência. & $\begin{array}{l}\text { Art. 1.025 } \\
\text { acórdão os elementos que o embargante } \\
\text { suscitou, para fins de prequestionamento, } \\
\text { ainda que os embargos de declaração } \\
\text { sejam inadmitidos ou rejeitados, caso o } \\
\text { tribunal superior considere existentes }\end{array}$ \\
\hline
\end{tabular}

${ }^{78}$ Correspondência no Anteprojeto: art.940 
Rio de Janeiro. Ano 10. Volume 17. Número 2. Julho a Dezembro de 2016

Periódico Semestral da Pós-Graduação Stricto Sensu em Direito Processual da UERJ

Patrono: José Carlos Barbosa Moreira. ISSN 1982-7636. pp. 579-622 www.redp.uerj.br

\begin{tabular}{|c|c|}
\hline & omissão, contradição ou obscuridade. \\
\hline $\begin{array}{l}\text { Art. 538. Os embargos de declaração } \\
\text { interrompem o prazo para a interposição } \\
\text { de outros recursos, por qualquer das } \\
\text { partes. } \\
\text { Parágrafo único. Quando manifestamente } \\
\text { protelatórios os embargos, o juiz ou o } \\
\text { tribunal, declarando que o são, condenará } \\
\text { o embargante a pagar ao embargado multa } \\
\text { não excedente de } 1 \% \text { (um por cento) sobre } \\
\text { o valor da causa. Na reiteração de } \\
\text { embargos protelatórios, a multa é elevada } \\
\text { a até } 10 \% \text { (dez por cento), ficando } \\
\text { condicionada a interposição de qualquer } \\
\text { outro recurso ao depósito do valor } \\
\text { respectivo. }\end{array}$ & $\begin{array}{l}\text { Art. 1.02679. Os embargos de declaração } \\
\text { não possuem efeito suspensivo e } \\
\text { interrompem o prazo para a interposição } \\
\text { de recurso. } \\
\S 1^{\circ} \text { A eficácia da decisão monocrática ou } \\
\text { colegiada poderá ser suspensa pelo } \\
\text { respectivo juiz ou relator se demonstrada } \\
\text { a probabilidade de provimento do recurso } \\
\text { ou, sendo relevante a fundamentação, se } \\
\text { houver risco de dano grave ou de difícil } \\
\text { reparação. } \\
\S 2^{\circ} \text { Quando manifestamente protelatórios } \\
\text { os embargos de declaração, o juiz ou o } \\
\text { tribunal, em decisão fundamentada, } \\
\text { condenará o embargante a pagar ao } \\
\text { embargado multa não excedente a dois } \\
\text { por cento sobre o valor atualizado da } \\
\text { causa. } \\
\S \text { } 3^{\circ} \text { Na reiteração de embargos de } \\
\text { declaração manifestamente protelatórios, } \\
\text { a multa será elevada a até dez por cento } \\
\text { sobre o valor atualizado da causa, e a } \\
\text { interposição de qualquer recurso ficará } \\
\text { condicionada ao depósito prévio do valor } \\
\text { da multa, à exceção da Fazenda Pública e } \\
\text { do beneficiário de gratuidade da justiça, } \\
\text { que a recolherão ao final. } \\
\S 4^{\circ} \text { Não serão admitidos novos embargos }\end{array}$ \\
\hline
\end{tabular}

${ }^{79}$ Correspondência no Anteprojeto: art.941 
Revista Eletrônica de Direito Processual - REDP.

Rio de Janeiro. Ano 10. Volume 17. Número 2. Julho a Dezembro de 2016

Periódico Semestral da Pós-Graduação Stricto Sensu em Direito Processual da UERJ

Patrono: José Carlos Barbosa Moreira. ISSN 1982-7636. pp. 579-622 www.redp.uerj.br

de declaração se os 2 (dois) anteriores

houverem sido considerados protelatórios.

Sem a intenção de esgotar o debate sobre as alterações propostas pelo novo Código de Processo Civil no que se refere aos embargos de declaração, optamos por fazer uma resenha geral das principais alterações empreendidas pelo legislador, conforme roteiro que segue:

\subsection{AS PRINCIPAIS QUESTÕES QUE ENVOLVEM PRAZO PARA MANEJO}

O legislador manteve a mesma posição adotada pelo CPC de 1973 quanto à fixação do prazo de 5 (cinco) dias para a interposição dos embargos declaratórios e, assim, não dissipou a divergência com o Código Eleitoral, pois como já vimos o prazo de aviamento desse tipo de recurso no processo eleitoral é de 3 (três) dias.

Há previsão expressa na nova redação do art. 275 do Código Eleitoral acerca da interrupção do prazo recursal, alteração está que pode ser vista no seu $\S 5^{\circ}$, não se cogitando mais em simples suspensão do prazo, diante da mudança que se inseriu pelo art. 1.067 do novo CPC.

Um ponto merece ser observado. Com efeito, durante os intensos debates legislativos que cercaram esse novo diploma legal, quadra destacar aquela que se dispôs quanto ao regime de interrupção do prazo para outros recursos que deu origem ao artigo 1.026. Houve uma tentativa no Senado de determinar a não interrupção do prazo em casos de intempestividade somente ao embargante. Todavia, essa proposta não foi acolhida pela redação final do CPC 15. Manteve-se a ideia do texto original de que caso embargos viessem ser declarados como intempestivos, esses não interromperiam o prazo de outros recursos, para ambas as partes processuais. Entretanto, deve-se prevalecer a inteligência do texto proposto pelo Senado. Ora, não se pode pensar que a intempestividade do recurso de uma parte possa influir na preservação do prazo de outra, notadamente antagônica, pois 
Revista Eletrônica de Direito Processual - REDP.

Rio de Janeiro. Ano 10. Volume 17. Número 2. Julho a Dezembro de 2016

Periódico Semestral da Pós-Graduação Stricto Sensu em Direito Processual da UERJ

Patrono: José Carlos Barbosa Moreira. ISSN 1982-7636. pp. 579-622

www.redp.uerj.br

não há qualquer meio seguro da segunda contraparte aferir (e controlar) a tempestividade dos embargos de declaração ofertados por outro litigante ${ }^{80}$.

Outra questão interessante diz respeito à aplicação de prazo em dobro para apresentação de embargos de declaração quando se tratar de litisconsortes com procuradores diversos (artigo 229 ${ }^{81}$ ). A “novidade” segue a linha de codificação de práticas consagradas nos Tribunais pátrios ${ }^{82}$, mas merece ser absorvida com cuidados nas leis especiais, eis que em alguns microssistemas a dilação de prazo em situações semelhantes não tem sido recepcionada, como é o caso da Justiça do Trabalho ${ }^{83}$ e da Justiça Eleitoral. ${ }^{84}$ Acreditamos que, como a não aceitação de dilação de prazo para as hipóteses de litisconsortes diversos se trata de posição firmada em diretriz do processo eleitoral (celeridade), a alteração pretendida pelo 'novo' Código de Processo Civil, embora planejada para a aplicação supletiva e subsidiária às leis especiais citadas, provavelmente não terá eco.

Por fim, a contagem de prazos em dias úteis (art. 219 do CPC-15) afigura-se como regra contrária a essência de celeridade do processo eleitoral, fazendo com o que, provavelmente, não seja absorvida nas ações eleitorais.

\footnotetext{
${ }^{80}$ Parecendo concordar com nossa opinião, confir-se: Daniel Ustárroz e Sergio Gilberto Porto (Manual dos recursos cíveis. $3^{\mathrm{a}}$. ed. Porto Alegre: Livraria do Advogado, 2011, p. 205).

${ }^{81}$ Art. 229. Os litisconsortes que tiverem diferentes procuradores, de escritórios de advocacia distintos, terão prazos contados em dobro para todas as suas manifestações, em qualquer juízo ou tribunal, independentemente de requerimento.

82 "PROCESSUAL CIVIL. EMBARGOS DE DECLARAÇÃO. LITISCONSORTES COM PROCURADORES DIVERSOS. PRAZO RECURSAL EM DOBRO. ART. 191 DO CPC. EMBARGOS DE DECLARAÇÃO TEMPESTIVOS. PRECEDENTES DO STJ. OMISSÃO. NÃO OCORRÊNCIA. 1. A existência de litisconsórcio com procuradores diversos revela direito ao prazo recursal em dobro, ante a ratio essendi do art. 191, do CPC. Precedentes jurisprudenciais do STJ: RESP 713367/SP, desta relatoria, DJ de 27.06.2005 e EDcl no AgRg no Ag 507546 / RJ, Relator Ministro Jorge Scartezzini, DJ de 01.08.2005. (...) (STJ, 2005/0128562-7, Primeira Turma Ministro Luiz Fux, Publicado em 05/03/2009.

${ }^{83}$ Firmou-se o entendimento de que este dispositivo está alijado das ações trabalhistas, ao argumento de que fere a celeridade processual (cláusula pétrea do processo do trabalho), ou seja, o prazo será singular mesmo que ocorra litisconsórcio e as partes, em tal situação, possuam advogados distintos. Tanto assim que o Tribunal Superior do Trabalho firmou a posição através da OJ SDI-I n. 310, nos seguintes termos: “A regra contida no art. 191 do CPC é inaplicável ao processo do trabalho, em face da sua incompatibilidade com o princípio da celeridade inerente ao processo trabalhista." Na doutrina, confira-se: Contra: entendendo pela aplicação do Decreto-lei 779/1969 no âmbito dos embargos de declaração: Denise Alves Horta (Embargos de declaração: regime legal e suas hipóteses. In Embargos de declaração no processo do trabalho. Vitor Salino de Moura Eça (Coord.). São Paulo: LTr, 2010, p. 32).

${ }^{84}$ No sentido, confira-se, no presente texto, a parte final do item 3.
} 
Rio de Janeiro. Ano 10. Volume 17. Número 2. Julho a Dezembro de 2016

Periódico Semestral da Pós-Graduação Stricto Sensu em Direito Processual da UERJ

Patrono: José Carlos Barbosa Moreira. ISSN 1982-7636. pp. 579-622

www.redp.uerj.br

\subsection{CABIMENTO CONTRA QUALQUER TIPO DE DECISÃO JUDICIAL}

Diante da redação mais técnica do artigo 1.022, que indica expressamente o cabimento de embargos contra qualquer tipo de decisão, não resta dúvidas que o princípio da ampla embargabilidade inserirá no âmbito do processo eleitoral, alternando-lhe, já que essa orientação principiologica não era recepcionada de forma unanime pela jurisprudência e doutrina, como antes demonstramos.

\section{3 'ALARGAMENTO' DAS HIPÓTESES DE OPONIBILIDADE DE EMBARGOS DE DECLARAÇÃO}

O erro material foi incluído como hipótese de oponibilidade dos embargos de declaração (construção também a muito consagrada na doutrina e jurisprudência) ${ }^{85}{ }^{86}$.

Destaque-se o parágrafo único do artigo 1.022, que indica como omissa a decisão que não se manifesta sobre tese firmada em julgamento de casos repetitivos ou em incidente de assunção de competência. Importante notar que esse dispositivo possui natureza apenas didática, ou seja, o rol que apresenta é apenas exemplificativo quanto às hipóteses de omissão (vinculados a novos dispositivos do CPC 15). Para tanto, basta observar que o fenômeno da omissão pode ocorrer com variações.

Com efeito, será omisso o ato judicial que deixar de deliberar acerca de questão relevante trazida por postulação para debate pelas partes (fenômeno da omissão direta), como também haverá omissão nos casos em que o ato judicial deixar de se pronunciar

\footnotetext{
${ }^{85} \mathrm{Na}$ verdade, o erro material como causa de oponibilidade dos embargos de declaração é hipótese que pode ser encartada como omissão indireta, eis que passível de argüição de ofício pelo órgão julgador, ou seja, já deveria ter sido resolvida pelo órgão jurisdicional que, não o fazendo de ofício, se torna omisso. Adiante, no corpo do texto, tratamos do fenômeno da omissão indireta.

${ }^{86}$ No sentido (entre vários): “Os embargos de declaração são cabíveis quando o provimento jurisdicional padece de omissão, contradição ou obscuridade, consoante dispõe o art. 535, I e II, do CPC, bem como para sanar a ocorrência de erro material” (STJ, EDcl no AgRg no Ag 1207351/BA, Rel. Ministro BENEDITO GONÇALVES, PRIMEIRA TURMA, julgado em 16/08/2011, DJe 19/08/2011).
} 
Revista Eletrônica de Direito Processual - REDP.

Rio de Janeiro. Ano 10. Volume 17. Número 2. Julho a Dezembro de 2016

Periódico Semestral da Pós-Graduação Stricto Sensu em Direito Processual da UERJ

Patrono: José Carlos Barbosa Moreira. ISSN 1982-7636. pp. 579-622

www.redp.uerj.br

sobre questão que, embora não tenha sido suscitada pelo(s) interessado(s), deveria ter sido resolvida de ofício pelo julgador, eis que independe de provocação das partes e não foi acometida pelos efeitos da preclusão (omissão indireta). ${ }^{87} \mathrm{Em}$ suma, não apenas as questões trazidas pelas partes podem gerar a omissão, haja vista que a falta de atividade judicial sobre matéria que o Judiciário poderia (deveria) se manifestar (e resolver) de ofício também é capaz de gerar a omissão. Há, nessa situação, como vimos, o fenômeno da omissão indireta. ${ }^{88}$ Para que não fique dúvida sobre o tema (e não se feche a temática da omissão indireta em um outra situação pontual), é salutar trazer outros exemplos de matérias que devem ser resolvidas pelo julgador, ainda que não invocadas pelas partes: (a) matérias de ordem pública não analisadas ${ }^{89}$; (b) aplicação de juros e correção (com toda

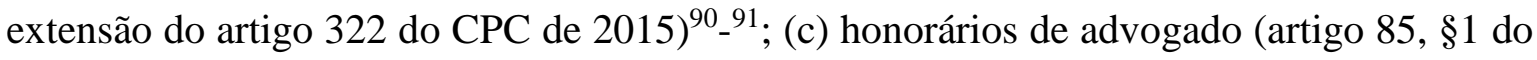
$\mathrm{CPC})^{92}$; (d) prestações periódicas artigo 323 do CPC) $)^{93}$; (e) fato superveniente (artigo 493

87 Tratamos do tema com vagar na nossa tese de doutoramento (Embargos de Declaração: Recurso de saneamento com função constitucional. FADISP, Orientação Eduardo Arruda Alvim, 2012, p. 321-325) e em artigo específico sobre o tema: Embargos de declaração e a omissão indireta (matérias que devem ser resolvidas de ofício, independentemente de arguição prévia pelo interessado). In: Os poderes do juiz e o controle das decisões judiciais: estudos em homenagem à Professora Teresa Arruda Alvim Wambier. José Miguel Garcia Medina; Luana Pedrosa de Figueiredo Cruz; Luis Otávio Sequeira de Cerqueira; Luiz Manoel Gomes Junior. (Orgs.). São Paulo: Revista dos Tribunais, 2008, p. 57-78.

${ }^{88}$ No sentido: STJ, EDcl nos EDcl no RMS 66/DF, Rel. Ministra Eliana Calmon, Segunda Turma, j. 23.05.2000, DJ 28.08.2000, p. 64; AgRg nos EDcl no Ag 778.452/SC, Rel. Ministro LUIS FELIPE SALOMÃO, QUARTA TURMA, julgado em 17/03/2011, DJe 23/03/2011.

${ }^{89}$ No sentido: "O Colendo Superior Tribunal de Justiça pacificou entendimento no sentido de que o Tribunal deve pronunciar-se sobre as questões de ordem pública, ainda que suscitadas tão-somente em embargos de declaração, haja vista ser um dever para o Estado-Juiz o exame das matérias apreciáveis de ofício, acarretando omissão a não observância das questões indisponíveis" (TJES, EDMS n. 100.03.002761-7, Tribunal Pleno, Relator Desembargador Sérgio Bizzotto Pessoa de Mendonça, j. 28.07.2007, DJ 22/08/2005). Bem próximo: TJES, ED na Apelação Cível 024.94.007280-4, 3ª Câmara Cível, Rel. Desembargador Substituto Robson Luiz Albanez, j. 06.03.2007, DJ 20.03.2007.

${ }^{90}$ Confira-se: "Tratando-se, os juros moratórios, de incidência decorrente de lei (CPC, art. 293), embora nas razões da apelação o apelante-embargante não tenha expressamente requerido a aplicação de juros de mora, deve o Órgão Julgador manifestar-se a respeito da incidência desse encargo, no momento em que reforma a sentença e condena as rés a indenizar o autor por danos morais" (TJRS, Embargos de Declaração $n^{\circ}$ 70009892191, Nona Câmara Cível, Relator Desembargador Adão Sérgio do Nascimento Cassiano, j. 17/11/2004). Próximos: TJRS, ED no 70011807450, Nona Câmara Cível, Relatora Dês. Iris Helena Medeiros Nogueira, j. 08/06/2005; STJ, EDcl no REsp 468.903/RJ, Rel. Ministro Hélio Quaglia Barbosa, Quarta Turma, j. 17.04.2007, DJ 21.05.2007, p. 581; STJ, EDcl no REsp 698.772/MG, Rel. Ministra Nancy Andrighi, Terceira Turma, j. 19.09.2006, DJ 02.10.2006, p. 265; STJ, AgRg no REsp 1049826/SP, Rel. Ministro ALDIR PASSARINHO JUNIOR, QUARTA TURMA, julgado em 22/03/2011, DJe 25/03/2011.

${ }^{91} \mathrm{Na}$ doutrina, sobre embargos de declaração e os pedidos implícitos, confira-se; Júlio Bernardo do Carmo (Embargos de declaração: visão geral e prequestionamento. No âmbito do processo do trabalho. In Embargos de declaração no processo do trabalho. Vitor Salino de Moura Eça (Coord.). São Paulo: LTr, 2010, p. 103104).

92 Confira-se: STJ, AgRg no REsp 886.559/PE, Rel. Ministro Francisco Falcão, Primeira Turma, j. 24.04.2007, DJ 24.05.2007, p. 329). Em termos: STJ, EDcl no AgRg no REsp 380.831/SC, Rel. Ministro 
Revista Eletrônica de Direito Processual - REDP.

Rio de Janeiro. Ano 10. Volume 17. Número 2. Julho a Dezembro de 2016

Periódico Semestral da Pós-Graduação Stricto Sensu em Direito Processual da UERJ

Patrono: José Carlos Barbosa Moreira. ISSN 1982-7636. pp. 579-622

www.redp.uerj.br

do CPC $)^{94}{ }^{95}$; (f) material levado pelo efeito devolutivo do apelante (artigo 1.013, $\S 2^{\circ}$, do

(PC) $)^{96}$.

Portanto, a redação final do novo diploma processual civil, a qual considera como omissa a decisão que não aduz sobre tese firmada em julgamento de casos repetitivos ou em incidente de assunção de competência, apenas detalha exemplos de omissão indireta, já que faz alusão à omissão nos casos em que o órgão jurisdicional devia, de ofício ou a requerimento da parte, pronunciar-se.

\subsection{PREQUESTIONAMENTO}

$\mathrm{O}$ art. 1.025 introduz no corpo do Código Processual Civil regramento para efeito de prequestionamento, considerando a possibilidade de inserir (por ficção) no acórdão, as questões tratadas nos embargos de declaração com este fim, mesmo que não sejam julgadas. A redação do dispositivo em voga não deixa dúvida, pois sua dicção aduz que serão considerados incluídos no acórdão os elementos que o embargante suscitou, para fins de prequestionamento, ainda que os embargos de declaratórios sejam inadmitidos ou rejeitados, na hipótese do tribunal superior considerar inexistentes erro, omissão, contradição ou obscuridade.

Vicente Leal, Sexta Turma, j. 06.08.2002, DJ 02.09.2002, p. 258; STJ, EDcl no REsp 369.773/ES, Rel. Ministro Garcia Vieira, Primeira Turma, j. 05.09.2002, DJ 28.10.2002, p. 226; STJ, EDcl no REsp 1004258/SC, Rel. Ministro MAURO CAMPBELL MARQUES, SEGUNDA TURMA, julgado em 17/02/2011, DJe 10/03/2011.

93 Confira-se: TJRS, Embargos de Declaração no 70018734061, Décima Oitava Câmara Cível, Relator Desembargador André Luiz Planella Villarinho, j. 22/03/2007.

${ }^{94}$ Confira-se: "Cabíveis embargos declaratórios para sanar omissão de acórdão que não aplicou, de oficio, direito superveniente (arts. 462 c/c 535, II, do CPC)" (STJ, REsp. 5.708/SP, Rel. Ministro Humberto Gomes de Barros, Primeira Turma, julgado em 01.09.1991, DJ 30.09.1991, p. 13464).

$95 \mathrm{Na}$ doutrina, confira-se: Humberto Theodoro Júnior (Embargos de Declaração. Remédio hábil para introduzir o julgamento o ius superveniens (art. 462 do CPC). In. Estudos em homenagem à professora Ada Pellegrinni Grinover. Flávio Luiz Yarshell e Maurício Zanoíde de Moraes (Orgs.). São Paulo: DPJ Editora, 2005, p. 601-618)..

96 Confira-se: STJ, REsp. 136.550/MG, Relator Ministro Cesar Asfor Rocha, Quarta Turma, j. 23.11.1999, DJ 08.03.2000, p. 118; STJ, REsp. 172.266/MG, Relator Ministro Aldir Passarinho Júnior, 4ª. Turma, DJ 08.10.2001, p. 218; STJ, 4 a Turma, REsp. 118.590/PR, DJ DATA: 30/06/2003, p. 00250, Relator Min. BARROS MONTEIRO. 
Revista Eletrônica de Direito Processual - REDP.

Rio de Janeiro. Ano 10. Volume 17. Número 2. Julho a Dezembro de 2016

Periódico Semestral da Pós-Graduação Stricto Sensu em Direito Processual da UERJ

Patrono: José Carlos Barbosa Moreira. ISSN 1982-7636. pp. 579-622

www.redp.uerj.br

Não há dúvida que o art. 1.025 está em dissonância com o posicionamento que se

firmou no Superior Tribunal de Justiça e é extratizado na Súmula 211 daquela Corte. ${ }^{97}$

Sem se alongar sobre a possibilidade de lei infraconstitucional definir os contornos do prequestionamento - cuja raiz é constitucional (fato que pode colocar em xeque a pretensão legislativa), a alteração - se recebida como regra processual supletiva e subsidiária - poderá ter repercussão importante no processo eleitoral, eis que o Tribunal Superior Eleitoral tem perfilado entendimento que prestigia a Súmula 211 do Superior Tribunal de Justiça. ${ }^{98}$

\subsection{RATIFICAÇÃO DE RECURSO EXCEPCIONAL}

Os $\S \S 4^{\circ}$ e $5^{\circ}$ do art. 1.024 neutralizam o disposto na Súmula 418 do Superior Tribunal de Justiça ${ }^{99}$, pois dispensa a ratificação do recurso interposto após o julgamento dos embargos de declaração ofertados pela outra parte anteriormente, desde que não ocorra a alteração da conclusão decisória.

A alteração é salutar e será utilizada como ferramenta para agilização da subida dos recursos ao Tribunal Superior Eleitoral, e, certamente, será bem recepcionada, pois prestigia a celeridade processual, diretriz de condução de todo processo eleitoral.

\subsection{APENAMENTO PELO USO DE EMBARgOS DE DECLARAÇÃo MANIFESTAMENTE PROTELATÓRIOS}

\footnotetext{
97 Súmula 211 do STJ: "Inadmissível recurso especial quanto à questão que, a despeito da oposição de embargos declaratórios, não foi apreciada pelo Tribunal a quo"

${ }^{98}$ Em suma, atualmente vige entendimento de que para efeito de prequestionamento na Justiça Eleitoral não basta o manejo dos embargos de declaração, sendo necessário que a questão seja efetivamente decidida na jurisdição ordinária. No sentido: "As questões federais e constitucionais não enfrentadas pelo Tribunal de origem, a despeito da oposição de embargos de declaração, recebem o óbice das Súmulas nos 282 do STF e 211 do STJ, não podendo, por falta de prequestionamento, ser debatidas no âmbito do recurso especial eleitoral” (TSE, Embargos de Declaração em Recurso Especial Eleitoral no 372068, Acórdão de 07/10/2010, Relator Ministro ALDIR GUIMARÃES PASSARINHO JUNIOR, publicado em sessão, 07/10/2010). Igualmente: TSE, Agravo Regimental em Recurso Especial Eleitoral no 36312, Acórdão de 18/03/2010, Relator Ministro MARCELO HENRIQUES RIBEIRO DE OLIVEIRA, DJE 12/05/2010, p. 47.

99 Súmula 418 do STJ: "É inadmissível o recurso especial interposto antes da publicação do acórdão dos embargos de declaração, sem posterior ratificação."
} 
Revista Eletrônica de Direito Processual - REDP.

Rio de Janeiro. Ano 10. Volume 17. Número 2. Julho a Dezembro de 2016

Periódico Semestral da Pós-Graduação Stricto Sensu em Direito Processual da UERJ

Patrono: José Carlos Barbosa Moreira. ISSN 1982-7636. pp. 579-622

www.redp.uerj.br

Antes da entrada em vigor do CPC-15 havia entendimento absolutamente equivocado no sentido de que seria possível bloquear o(s) recurso(s) posterior(es) a partir da asserção judicial de que os embargos de declaração são manifestamente protelatórios. Trata-se de apenamento que foi inspirado no Código de Processo Civil de 1939 e que foi permutado pela multa pecuniária na codificação de 1973, sendo tal modificação aplicável ao processo eleitoral. ${ }^{100}{ }^{101}$

Assim, considerando que o apenamento aos embargos de natureza manifestamente protelatória no processo eleitoral é a multa pecuniária do Código de Processo Civil, há alterações que merecem ser destacadas, pois algumas poderão ser aplicadas em sede de ações eleitorais.

100 O disposto no $\S 5^{\circ}$ do artigo 862 do Código de Processo Civil de 1939 sempre foi alvo de aguda e torrencial crítica, notadamente na sua redação primitiva (em que a rejeição dos embargos de declaração não preservava o prazo dos recursos posteriores). Diante da insegurança que a aplicação da regra provocava, o Supremo Tribunal Federal, conforme bem lembra a doutrina, chegou a fixar entendimento de que o $\S 5^{\circ}$ do artigo 862 (na sua redação original) era aplicável apenas aos recursos de índole ordinária, ou seja, a Excelsa Corte lhe deu interpretação limitada. Mesmo com a alteração redacional (efetuada pelo Decreto-Lei $n$ 8.570/1946), que resultou em dispositivo com visível semelhança ao $\S 4^{\circ}$ do artigo 275 do Código Eleitoral (até porque este é datado na vigência do diploma processual de 1939), o $\S 5^{\circ}$ do artigo 862 do Código de Processo Civil não deixou de ser motivo de censura, o que ocasionou seu descarte do processo civil comum em 1973, com a então nova codificação. Assim, a interdição recursal do artigo 862 , $\S 5^{\circ}$, do Código de Processo Civil de 1939, foi permutada pela multa pecuniária prevista no parágrafo único do artigo 538 do Código de Processo Civil. O bloqueio recursal, previsto também na nova legislação processual civil, somente é admitido como conseqüência (residual) do não depósito da multa protelatória, nos casos em que expressamente declarado que o depósito da multa é pressuposto para o trânsito de recurso posterior. A interpretação histórica, na forma acima apresentada, não pode ser descartada, pois é simplista a afirmação de que o artigo 538 do Código de Processo Civil de 1973, ora artigo 1.026 do CPC de 2015, não é excludente do artigo 275, $\S 4^{\circ}$, do Código Eleitoral (TSE AGRAVO REGIMENTAL EM AGRAVO DE INSTRUMENTO n $^{\circ}$ 2105, 23/05/2000, Relator Min. MAURÍCIO JOSÉ CORRÊA), pois, ao contrário da fala supra, o primeiro artigo veio para ocupar o espaço de dispositivo que detinha igual arquitetura do último e, repita-se, lhe deu inspiração.

101 Aplicando a multa e juntamente bloqueio de recurso posterior, confira-se: "Embargos de declaração. Agravo regimental. Agravo de instrumento. Ação penal. Embargos protelatórios. Não-conhecimento. 1. A simples reiteração dos argumentos anteriormente apresentados à Corte, que sobre eles expressamente se pronunciou, revela nítido caráter protelatórios dos embargos de declaração. (...) Não demonstradas as hipóteses do art. 275 do Código Eleitoral, não se conhece dos declaratórios, declarando-os protelatórios, aplicando-se, ainda, a pena de multa e determinando-se a certificação do trânsito em julgado do feito, independentemente de publicação do acórdão" (TSE, Embargos de Declaração dm Embargos de Declaração em Agravo Regimental em Embargos de Declaração em Embargos de Declaração em Agravo de Instrumento n 5902 , Acórdão de 06/03/2007, Relator(a) Min. CARLOS EDUARDO CAPUTO BASTOS, Publicação: DJ - Diário da Justiça, Data 03/04/2007, p.130 - destaque nosso). 
Revista Eletrônica de Direito Processual - REDP.

Rio de Janeiro. Ano 10. Volume 17. Número 2. Julho a Dezembro de 2016

Periódico Semestral da Pós-Graduação Stricto Sensu em Direito Processual da UERJ

Patrono: José Carlos Barbosa Moreira. ISSN 1982-7636. pp. 579-622

www.redp.uerj.br

$\mathrm{O}$ artigo 1.026 dispõe que: i) instaura-se o valor limite da multa aplicável para até

$2 \%$ (dois por cento) do valor da causa; ii) havendo reiteração de embargos protelatórios, eleva-se a multa a até 10\% (dez por cento) do valor da causa; iii) não mais se admite novos embargos, se os dois anteriores houverem sido considerados protelatórios; iv) há previsão expressa da dispensa de depósito da multa para interposição de outro recurso por parte da Fazenda Pública e dos beneficiários da gratuidade de justiça ${ }^{102}$.

A nova redação do art. 275 do Código Eleitoral, deflagrada pelo art. 1.067 do novo CPC, torna-se crucial para se afastar o equivocado entendimento que confundia a aplicação das penas previstas pelas codificações de 1939 e 1973.

\subsection{EFEITO SUSPENSIVO}

De acordo com o artigo 1.026 do CPC 15, os embargos de declaração poderão ter excepcional efeito suspensivo, se configurada a probabilidade de provimento recursal ou se configurado o risco de grave dano ou de difícil reparação. Embora o texto não informe serem cumulativos os requisitos (probabilidade + risco), na nossa opinião, deverão estar demonstrados de forma conjunta tais pressupostos para a concessão do (incomum) efeito suspensivo.

A redação do dispositivo não indica se há a necessidade de pedido da parte interessada para a concessão do efeito suspensivo na espécie de recurso aqui reportada, dando a impressão de que o órgão julgador poderá concedê-lo de ofício, não sendo, assim, hipótese exclusiva, de concessão provocada, isto é, mediante postulação do interessado.

Cremos que não há qualquer motivo para que a novidade seja rejeitada no processo eleitoral, uma vez que - como é curial - muitas decisões proferidas em tal justiça especializada possuem alto risco de grave dano ou de difícil reparação. Dessa forma, o artigo 257 do Código Eleitoral, que indica que os recursos eleitorais não possuem efeito 
Revista Eletrônica de Direito Processual - REDP.

Rio de Janeiro. Ano 10. Volume 17. Número 2. Julho a Dezembro de 2016

Periódico Semestral da Pós-Graduação Stricto Sensu em Direito Processual da UERJ

Patrono: José Carlos Barbosa Moreira. ISSN 1982-7636. pp. 579-622

www.redp.uerj.br

suspensivo, poderá ser mitigado a partir da solução apresentada pelo ‘novo' Código de Processo Civil.

\section{BREVE FECHAMENTO}

O presente artigo não esgotou o tema, mas estabeleceu um panorama entre as peculiaridades quanto aos embargos de declaração no âmbito do direito eleitoral e as diferentes normas e influências que o processo civil exerce nesta temática (apontando dispositivos e posicionamentos adotados pelas duas legislações pretéritas e pelo texto legal vigente). Diante dessa analise sistêmica, fácil reconhecer as antigas desarmonias que vigeram dentro do nosso ordenamento e que, por objetivo louvável e claro do legislador de trazê-lo unicidade, foram amenizadas (mas não eliminadas).

Em resenha, a partir do disposto no art. 15 do CPC-15 - como fonte supletiva e subsidiária de toda a legislação processual - é imperioso que o processo eleitoral passe por uma releitura voltada para as diretrizes constitucionais. Feita essa releitura e aparando algumas arestas sistêmicas, o microssistema do direito eleitoral tende a ganhar uma leitura mais harmônica e orgânica.

Apesar dos pontos de divergência que resistem quanto a nova legislação processual civil, os embargos declaratórios no processo eleitoral passarão a ter uma redação mais adequada diante das retificações trazidas pelo art. 1.067 do NCPC/15.

\section{REFERÊNCIAS BIBLIOGRÁFICAS}

AGUIAR, Cristopher Rezende Guerra. Recursos na Justiça Eleitoral. In. Atualidades do Processo Civil. Arruda Alvim e Eduardo Arruda Alvim (coords.). Vol.I. Curitiba-PR: Juruá Editora, 2006.

ALVIM, Eduardo Arruda. Direito processual civil. 2a. São Paulo: Revista dos Tribunais. 
Revista Eletrônica de Direito Processual - REDP.

Rio de Janeiro. Ano 10. Volume 17. Número 2. Julho a Dezembro de 2016

Periódico Semestral da Pós-Graduação Stricto Sensu em Direito Processual da UERJ

Patrono: José Carlos Barbosa Moreira. ISSN 1982-7636. pp. 579-622

www.redp.uerj.br

ASSIS, Araken. Manual dos Recursos. 2.ed. ver. E ampl. São Paul: Revista dos Tribunais, 2008.

BERMUDES, Sérgio. Comentários ao Código de Processo Civil. 2a .ed., São Paulo: Revistas dos Tribunais, vol. 07.

CÂNDIDO, Joel José. Direito eleitoral brasileiro. 6. Ed.. São Paulo: Edipro, 1996.

COSTA, Tito. Recursos em Matéria Eleitoral. 9. Ed. Ver., atual e ampl. São Paulo: Revistas dos Tribunais, 2010.

COSTA, Adriano Soares. Instituições de Direito Eleitoral. 5.ed.. Belo Horizonte, Del Rey, 2002.

COSTA, Alfredo de Araújo Lopes. Manual elementar de direito processual. Rio de Janeiro: Forense, 1956.

DIDIER JR, Fredie e CUNHA, Leonardo José Carneiro. Curso de Direito Processual Civil: Meios de impugnação às decisões judiciais e processos nos tribunais. V1.3. 7.ed., Salvador: Editora Juspodivm, 2009.

FERRAZ, Sérgio. Recursos aos tribunais regionais. In. Direito Eleitoral. Carlos Mario da Silva Velloso e Carmen Lúcia Antunes Rocha (Coords.). Belo Horizonte; Del Rey, 1996.

GAJARDONI, Fernando da Fonseca. Flexibilização Procedimental. São Paulo: Atlas, 2008 .

JARDIM, Torquato. Introdução ao direito eleitoral positivo. Brasília: BraíliaJurídic,1994.

JORGE NETO, Francisco Ferreira e CAVALCANTE, Jouberto de Quadros Pessoa. Recursos no processo do trabalho. Rio de Janeiro: Lumen Juris, 2007. 
Revista Eletrônica de Direito Processual - REDP.

Rio de Janeiro. Ano 10. Volume 17. Número 2. Julho a Dezembro de 2016

Periódico Semestral da Pós-Graduação Stricto Sensu em Direito Processual da UERJ

Patrono: José Carlos Barbosa Moreira. ISSN 1982-7636. pp. 579-622

www.redp.uerj.br

LUCON, Paulo Henrique dos Santos; VIGILAR, José Marcelo Menezes. Código eleitoral interpretado.. $2^{a}$ ed. São Paulo: Atlas, 2011.

MAZZEI, Rodrigo Reis. In O manejo dos declaratórios pelo "terceiro prejudicado". Aspectos Polêmicos e Atuais sobre os Terceiros no Processo Civil e Assuntos Afins (Coord. Fredie Didier Jr. e Teresa Arruda Alvim Wambier). São Paulo: Revistas dos Tribunais, 2004 ..

In Dos Embargos de Declaração. Dos recursos - Temas obrigatórios e atuais (vetores recursais). Vitória: Instituto Capixaba de Estudos - ICE, 2002, v.2.

Embargos de declaração. Evolução legislativa em 30 anos de CPC. Horizontes de uma nova reforma. Linhas mestras do processo Civil (comemoração dos 30 anos de vigência do (PC). Helio Rubens Ribeiro Costa, José Horácio Halfeld Rezende Ribeiro e Pedro da Silva Dinamarco (coords.). São Paulo: Atlas, 2004.

Embargos de Declaração: Recurso de saneamento com função constitucional. Tese (Doutorado) - Faculdade Autonoma de Direito de São Paulo, 2012.

MEDEIROS, Hortência Catunda. Recursos atípicos. Rio de Janeiro: Forense, 1980.

MIRANDA, Pontes. Comentários ao código de processo civil. Tomo V. Rio de Janeiro: Forense, 1974.

MIRANDA, Vicente. Embargos de Declaração no Processo Civil Brasileiro. Saraiva: São Paulo, 1990.

MOREIRA, José Carlos Barbosa. Comentários ao Código de Processo Civil. $2^{\mathrm{a}}$.edição. Volume V. Rio de Janeiro: Editora Forense, 1976.

RIBEIRO, Flávia. Direito Eleitoral. 5.ed. Rio de Janeiro: Forense, 2000.

SOBREIRO NETO, Armando Antônio. Direito Eleitoral. 3ª ed.. Curitiba: Juruá, 2004. 
Revista Eletrônica de Direito Processual - REDP.

Rio de Janeiro. Ano 10. Volume 17. Número 2. Julho a Dezembro de 2016

Periódico Semestral da Pós-Graduação Stricto Sensu em Direito Processual da UERJ

Patrono: José Carlos Barbosa Moreira. ISSN 1982-7636. pp. 579-622

www.redp.uerj.br

SPADONI, Joaquim Felipe. A Função constitucional e outros meios de impugnação.

Volume. 8. Nelson Nery e Teresa Arruda Alvim Wambier (coords.).

TEIXEIRA, Freire de Barros. Teoria do Principio da Fungibilidade. São Paulo: Revista dos Tribunais, 2008.

TARDIN, Luiz Gustavo. Fungibilidade das Tutelas de Urgência. SÃO Paulo: Revistas dos Tribunais, 2006. 